\title{
High-level extracellular production of recombinant nattokinase in Bacillus subtilis WB800 by multiple tandem promoters
}

\author{
Zhongmei Liu* (D), Wenhui Zheng, Chunlei Ge, Wenjing Cui, Li Zhou and Zhemin Zhou*
}

\begin{abstract}
Background: Nattokinase (NK), which is a member of the subtilisin family, is a potent fibrinolytic enzyme that might be useful for thrombosis therapy. Extensive work has been done to improve its production for the food industry. The aim of our study was to enhance NK production by tandem promoters in Bacillus subtilis WB800.

Results: Six recombinant strains harboring different plasmids with a single promoter $\left(\mathrm{P}_{\text {P43, }}, \mathrm{P}_{\text {Hpall, }} \mathrm{P}_{\text {Bcapre, }} \mathrm{P}_{\text {gsiB, }}, \mathrm{P}_{\text {yxiE }}\right.$ or $\left.P_{\text {lux }}\right)$ were constructed, and the analysis of the fibrinolytic activity showed that $P_{P 43}$ and $P_{\text {Hpall }}$ exhibited a higher expression activity than that of the others. The NK yield that was mediated by $P_{P 43}$ and $P_{\text {Hpall }}$ reached $140.5 \pm 3.9$ $\mathrm{FU} / \mathrm{ml}$ and $110.8 \pm 3.6 \mathrm{FU} / \mathrm{ml}$, respectively. These promoters were arranged in tandem to enhance the expression level of NK, and our results indicated that the arrangement of promoters in tandem has intrinsic effects on the NK expression level. As the number of repetitive $P_{P_{43}}$ or $P_{H p a l l}$ increased, the expression level of NK was enhanced up to the triple-promoter, but did not increase unconditionally. In addition, the repetitive core region of $\mathrm{P}_{P_{43}}$ or $\mathrm{P}_{\text {Hpall }}$ could effectively enhance NK production. Eight triple-promoters with $\mathrm{P}_{443}$ and $\mathrm{P}_{\text {Hpall }}$ in different orders were constructed, and the highest yield of NK finally reached $264.2 \pm 7.0 \mathrm{FU} / \mathrm{ml}$, which was mediated by the promoter $\mathrm{P}_{\text {Hpall }} \mathrm{P}_{\text {Hpall }}-\mathrm{P}_{\text {P43 }}$. The scale-up production of NK that was promoted by $\mathrm{P}_{\text {Hpall }} \mathrm{P}_{\text {Hpall }}-\mathrm{P}_{\text {P43 }}$ was also carried out in a 5- $\mathrm{L}$ fermenter, and the NK activity reached $816.7 \pm 30.0 \mathrm{FU} / \mathrm{mL}$.

Conclusions: Our studies demonstrated that NK was efficiently overproduced by tandem promoters in Bacillus subtilis. The highest fibrinolytic activity was promoted by $P_{\text {Hpall }}-P_{\text {Hpall }} P_{P 43}$, which was much higher than that had been reported in previous studies. These multiple tandem promoters were used successfully to control NK expression and might be useful for improving the expression level of the other genes.
\end{abstract}

Keywords: Nattokinase, Tandem promoter, Core promoter region, Bacillus subtilis, Recombinant enzyme

\section{Background}

Nattokinase (NK, E.C. 3.4.21.62) was first identified by Sumi et al. from "Natto", which is a popular traditional Japanese soybean food [1]. NK, as a potent fibrinolytic enzyme, can directly cleave cross-linked fibrin in vitro and inactivate the fibrinolysis inhibitor or catalyze the conversion of plasminogen to plasmin [2,3]. Studies in rats showed that NK exhibited 5-fold more fibrinolytic activity than that of plasmin [4]. Compared with other thrombolytic reagents, including urokinase, tissue type plasminogen activator (t-PA) and streptokinase, NK has

\footnotetext{
* Correspondence: Imeimei1220@hotmail.com; zhmzhou@jiangnan.edu.cn Key Laboratory of Industrial Biotechnology (Ministry of Education), School of Biotechnology, Jiangnan University, 1800 Lihu Road, Wuxi 214122, Jiangsu,
} China

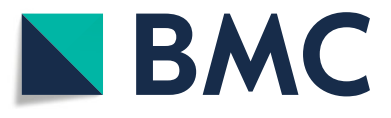

(c) The Author(s). 2019 Open Access This article is distributed under the terms of the Creative Commons Attribution 4.0 International License (http://creativecommons.org/licenses/by/4.0/), which permits unrestricted use, distribution, and reproduction in any medium, provided you give appropriate credit to the original author(s) and the source, provide a link to the Creative Commons license, and indicate if changes were made. The Creative Commons Public Domain Dedication waiver (http://creativecommons.org/publicdomain/zero/1.0/) applies to the data made available in this article, unless otherwise stated.

advantages in preventative and prolonged effects, with few side effects and stability in the gastrointestinal tract [5]. The NK gene was cloned and characterized, and protein engineering techniques and site-directed mutagenesis were carried out to improve NK stability [6-10]. The NK enzyme is usually industrially produced by the wild-type Bacillus subtilis natto (B. subtilis natto) [11].

The species $B$. subtilis is a good host strain for the industrial production of the NK enzyme, as NK was isolated from B. subtilis natto. B. subtilis is a gram-positive bacterium and is a well-studied host for the expression of heterologous proteins because of its many attractive features [12]. As a model organism, B. subtilis is widely used in laboratory studies because it is easy to culture and has a high-level secretory system. In addition, $B$. 
subtilis is a food-grade safety strain and presents no safety concerns, as reviewed by the U.S. FDA Center. Some efficient expression systems have been constructed to promote the production of homologous and heterologous proteins in B. subtilis, because of its well-characterized physiological and biochemical properties and nonpathogenicity [13-15]. B. subtilis strains has been engineered as extracellular-protease deficient strains for the overexpression of subtilisin and $\beta$-lactamase in B. subtilis WB600 [16, 17], the overexpression of staphylokinase and xylanase in $B$. subtilis WB700 $[18,19]$, and the overexpression of phospholipase C in B. subtilis WB800 [20]. In addition, several studies have reported the secretory overexpression of NK in recombinant B. subtilis strains [21, 22].

As is well known, the promoter-regulated gene transcription is usually located upstream of the gene. There are two kinds of promoters: the constitutive promoter that is active in all circumstances and the regulated promoter that become active only in response to specific stimulation in the cell. Because the promoter is a crucial aspect of the expression system, many strong promoters have been screened and characterized in B. subtilis [23-26]. Recent studies have increasingly focused on the strategy to improve the expression level of recombinant proteins or peptides by the construction of tandem promoters and promoter engineering. Using engineered promoters by altering the -10 or -35 region led to a much higher production of recombinant proteins [27, 28]. Widner et al. had studied the gene expression in B. subtilis and found that the expression level of the gene could increase by using expression systems that contain two or three tandem promoters in contrast to a single promoter. The study demonstrated that the expression of aprL achieved a high level by combining the mutant amyQ promoter with the promoter of the cry $3 A$ gene [29]. The thermostable 4- $\alpha$-glucanotransferase from Thermus scotoductus was overexpressed in B. subtilis, and its productivity was elevated by more than ten-fold when promoted by a dual-promoter system, compared to that of the single HpaII promoter system [30]. Researchers have investigated the strength of single and dual promoters for overexpression of aminopeptidase in B. subtilis. In addition, the dual-promoter $\mathrm{P}_{g s i B}-\mathrm{P}_{\text {HpaII }}$ gave the best performance, which was much higher than $\mathrm{P}_{\text {HpaII }}$ and $\mathrm{P}_{g s i B}$ [31]. The system containing a dual-promoter $\mathrm{P}_{\text {HpaII }}-\mathrm{P}_{a m y Q^{\prime}}$ was found to sustain superior expression of $\beta$-cyclodextrin glycosyltransferase in a $B$. subtilis strain (CCTCC M 2016536) [32]. Okegawa and Motohashi successfully expressed the functional ferredoxin-thioredoxin reductase by using a system containing tandem T7 promoters in Escherichia coli [33].
In this study, we aimed to increase the secretory expression of NK in B. subtilis WB800 by mediating the gene expression promotion by tandem promoters. Six constitutive promoters, $\mathrm{P}_{\text {HpaII }}, \mathrm{P}_{\text {P43 }}, \mathrm{P}_{\text {BcaprE }}, \mathrm{P}_{\text {lux } S}, \mathrm{P}_{\text {gsiB }}$ and $\mathrm{P}_{y x i E}$, were selected, and a series of expression cassettes containing single promoters, dual-promoters and triple-promoters was achieved by arranging promoters in different orders. The efficacies of these multiple tandem promoters for controlling the expression of NK are presented.

\section{Results}

Construction of expression cassettes for overexpression of nattokinase

Six strong and widely used promoters, $\mathrm{P}_{\text {HpaII }}, \mathrm{P}_{\text {P43 }}, \mathrm{P}_{\text {BcaprE }}$, $\mathrm{P}_{l u x S}, \mathrm{P}_{g s i B}$ and $\mathrm{P}_{y x i E}$, were selected as targets for enhancing the production of $\mathrm{NK}$, and their origins and characteristics are listed in Additional file 1: Table S1. The plasmid pSG- $\mathrm{P}_{\text {HpaII }}$ was constructed in our previous study [31]. Then, the plasmid pSG-pro-NK with no promoter was constructed first, and five promoters were employed to construct the plasmids pSG-P $P_{P 43}, \mathrm{pSG}-\mathrm{P}_{\text {BcaprE }}, \mathrm{pSG}$ $-\mathrm{P}_{\text {luxS }}$, pSG-P $\mathrm{P}_{\text {gsi }}$ and pSG-P $\mathrm{P}_{y x i E}$ following the MEGAWHOP method (Fig. 1a).

As shown in Fig. 1b, plasmids harboring multiple promoters in tandem were constructed ( $\mathrm{pSG}-\mathrm{P}_{\mathrm{X}}-\mathrm{P}_{\mathrm{Y}}-\mathrm{P}_{\mathrm{Z}}$ ). These six promoters were further inserted into the downstream region of different promoters to result in fourteen kinds of plasmids in which the NK was controlled by dual-promoters. Based on the NK expression level of recombinant strains under the control of dual-promoters, promoter P43 and HpaII were combined in the pattern of three and four promoters in tandem, and ten different kinds of promoters were successfully obtained.

In addition, another type of tandem promoter (pSG $\left.-n C P_{X}\right)$ was constructed, as shown in Fig. 1c. The core region of the promoter (-10 and - 35 region) was amplified and linked in tandem repeats. All of the plasmids for the NK expression that was constructed in this study are listed in Table 1.

\section{Expression of nattokinase in B. subtilis WB800 with a single promoter}

To compare the abilities of those six promoters to promote NK expression, the six strains harboring the different plasmids, pSG-P $\mathrm{P}_{\text {HpaII }}$, pSG-P $\mathrm{P}_{\text {P43 }}, \mathrm{pSG}-\mathrm{P}_{\text {BcaprE }}$, pSG-P $P_{l u x S}$, pSG-P $\mathrm{P}_{g s i B}$ and pSG-P $\mathrm{P}_{y x i E}$, were cultivated in TB medium. The effects of these single promoters on the secretory expression level of recombinant NK were determined by SDS-PAGE and fibrinolytic analysis (Fig. 2). Fibrinolytic activity curves showed that the highest activity was achieved at $36 \mathrm{~h}$ (Fig. 2a). The highest yield of NK mediated by $\mathrm{P}_{\text {HpaII }}$ was $110.8 \pm 3.6 \mathrm{FU} / \mathrm{ml}$, while the maximum NK activity 


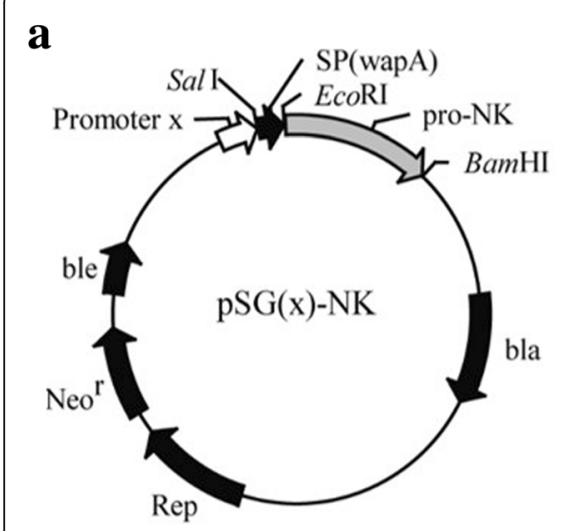

b

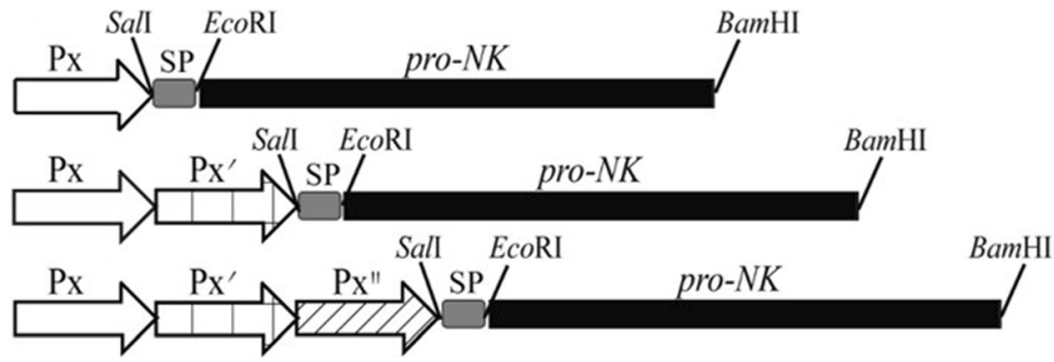

C

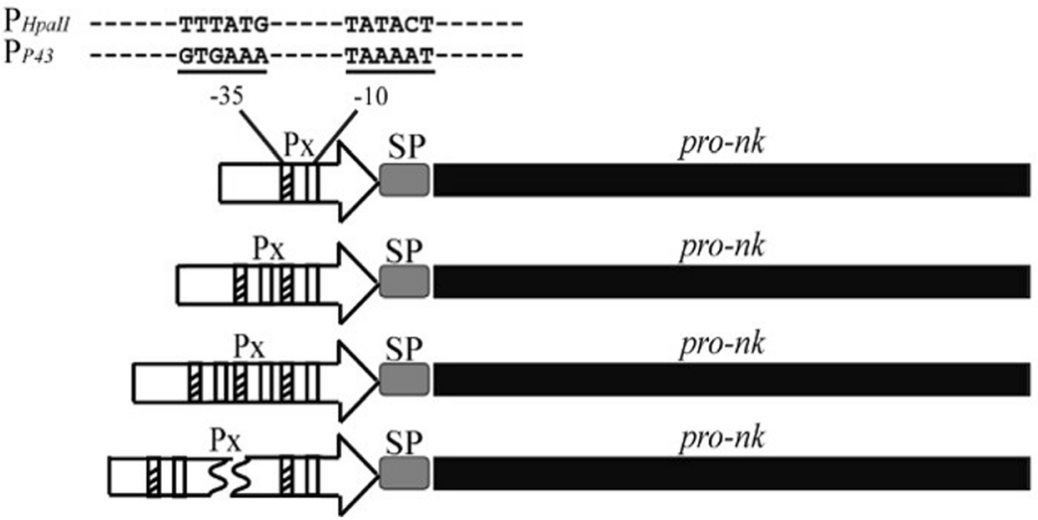

Fig. 1 Schematic representation of the expression cassettes. a Map of the $\mathrm{pSG}(\mathrm{x})$-NK vectors. All of the expression cassettes were cloned into the pMA0911-wapA-pro-NK, and the sites of the relevant restriction enzymes were shown. $\mathbf{b}$ The schematic diagram of the expression cassettes with tandem promoters. The signal peptide (SP) and the NK gene are represented by gray and black, respectively. The promoters, $\mathrm{P}_{\mathrm{X}}$, are represented by arrows. c The expression cassettes with repetitive core regions of promoters. The sequences of core regions $(-35$ and -10$)$ are shown

was $140.5 \pm 3.9 \mathrm{FU} / \mathrm{ml}$ produced by the strain harboring pSG- $P_{P 43}$. The expression levels under the control of $\mathrm{P}_{\text {BcaprE }}(103.5 \pm 4.2 \mathrm{FU} / \mathrm{ml})$ and $\mathrm{P}_{\text {luxS }}(99.2 \pm 3.8$ $\mathrm{FU} / \mathrm{ml}$ ) were similar, second only to the expression under the control of $\mathrm{P}_{\text {HpaII }}$. The promoter $\mathrm{P}_{y x i E}(20.2 \pm$ 2.0 FU/ml) exhibited the lowest expression level of NK among the six promoters, and its promoter strength was only $14 \%$ of $\mathrm{P}_{P 43}$. The results of SDS-PAGE and the fibrin plate assay supported the above fibrinolytic analysis results (Fig. 2b and c).

\section{Effects of different dual-promoter systems on nattokinase expression}

To investigate whether two of these promoters in tandem could enhance NK production, fourteen types of dual-promoters were constructed. The effects of these dual-promoter systems on the expression of recombinant NK were compared by SDS-PAGE and by measuring the fibrinolytic activity (Fig. 3). The NK expression from these dual-promoters containing two of the same promoters was constitutively increased compared with that from a single promoter, such as $\mathrm{P}_{P 43}-\mathrm{P}_{P 43}(157.2 \pm 3.0 \mathrm{FU} /$ $\mathrm{ml})$ compared with $\mathrm{P}_{P 43}(140.5 \pm 3.9 \mathrm{FU} / \mathrm{ml}), \mathrm{P}_{\text {HpaII }}-\mathrm{P}_{\text {HpaII }}$ $(199.4 \pm 4.8 \mathrm{FU} / \mathrm{ml})$ compared with $\mathrm{P}_{\text {HpaII }}(110.8 \pm 3.6 \mathrm{FU} /$ $\mathrm{ml}), \mathrm{P}_{\text {BcaprE }}-\mathrm{P}_{\text {BcaprE }}(120.3 \pm 2.4 \mathrm{FU} / \mathrm{ml})$ compared with $\mathrm{P}_{\text {BcaprE }}(103.5 \pm 4.2 \mathrm{FU} / \mathrm{ml})$, and $\mathrm{P}_{g s i B}-\mathrm{P}_{g s i B}(48.0 \pm 2.2 \mathrm{FU} /$ $\mathrm{ml})$ compared with $\mathrm{P}_{g s i B}(44.6 \pm 2.9 \mathrm{FU} / \mathrm{ml})$. These results showed that the experiments involving $\mathrm{P}_{g s i B}$ in tandem or separately did not exhibit an efficient expression of NK.

Intriguingly, the dual-promoter system containing different promoters showed that the order of two promoters has an important effect on the expression of NK. The NK activity under the control of $\mathrm{P}_{\text {HpaII }}-\mathrm{P}_{y x i E}$ was approximately $166.7 \pm 2.5 \mathrm{FU} / \mathrm{ml}$, but the production under the control of $\mathrm{P}_{y x i E^{-}} \mathrm{P}_{\text {HpaII }}$ displayed an obviously opposite effect, in which the expression of NK was undetected (0 $\mathrm{FU} / \mathrm{ml})$. Similar results were observed in strains harboring pSG-P $\mathrm{P}_{\text {gsiB }}-\mathrm{P}_{\text {HpaII }}(164.9 \pm 3.0 \mathrm{FU} / \mathrm{ml})$ and $\mathrm{pSG}-\mathrm{P}_{\text {HpaII }}-\mathrm{P}_{\text {gsi }}$ (0 $\mathrm{FU} / \mathrm{ml})$, pSG-P $\mathrm{P}_{\text {BcaprE }}-\mathrm{P}_{\text {HpaII }}(175.5 \pm 5.0 \mathrm{FU} / \mathrm{ml})$ and pSG-P $\mathrm{P}_{\text {HpaII }}-\mathrm{P}_{\text {BcaprE }}(0 \mathrm{FU} / \mathrm{ml})$, and pSG- $\mathrm{P}_{\text {luxS }}-\mathrm{P}_{\text {HpaII }}(77.5$ $\pm 4.0 \mathrm{FU} / \mathrm{ml})$ and $\mathrm{pSG}-\mathrm{P}_{\text {HpaII }}-\mathrm{P}_{\text {luxS }}(0 \mathrm{FU} / \mathrm{ml})$.

However, regardless of how $\mathrm{P}_{\text {HpaII }}$ and $\mathrm{P}_{P 43}$ were arranged in tandem, NK was expressed at a high level in the recombinant strain $B$. subtilis WB800. The NK yield mediated by $\mathrm{pSG}-\mathrm{P}_{P 43}-\mathrm{P}_{\text {HpaII }}$ reached the highest value $(231.7 \pm 6.0 \mathrm{FU} / \mathrm{ml})$, which increased by $109 \%$ when compared with $\mathrm{P}_{\text {HpaII }}$ and $64.9 \%$ when compared with $\mathrm{P}_{P 43}$. The strain harboring pSG- $\mathrm{P}_{\text {HpaII }}-\mathrm{P}_{P 43}$ exhibited the 
Table 1 Strains and plasmids used in this study

\begin{tabular}{|c|c|c|c|}
\hline Strains or plasmids & Description & Source & $\begin{array}{l}\text { Highest yield of NK (U/ } \\
\mathrm{mL})\end{array}$ \\
\hline \multicolumn{4}{|l|}{ Strains } \\
\hline $\begin{array}{l}\text { Escherichia coli } \\
\text { JM109 }\end{array}$ & $\begin{array}{l}\text { RecA1 pupE44 endA1 hsdR17 gyrA96 relA1 this(lac-proAB) F'[traD36 proAB }{ }^{+} \text {lacl } \\
\text { lacZ } \triangle \mathrm{M} 15]\end{array}$ & Lab stock & - \\
\hline $\begin{array}{l}\text { Bacillus subtilis } \\
\text { WB800 }\end{array}$ & nprE aprE epr bpr mpr::ble nprB::bsr $\Delta v p r$ wprA::hyg & Lab stock & - \\
\hline \multicolumn{4}{|l|}{ Plasmids } \\
\hline pMA0911-pro-NK & shuttle vector for $E$. coli/B. subtilis, $\mathrm{P}_{\text {Hpall, }} \mathrm{SP}_{\text {wapA, }}$ pro-NK, Ap', Km', & Lab stock & $110.8 \pm 5.2$ \\
\hline pSG-pro-NK & pMA0911-pro-NK without promoter $P_{\text {Hpall }}$ & $\begin{array}{l}\text { This } \\
\text { study }\end{array}$ & - \\
\hline pSG-P BcaprE & pSG-pro-NK with promoter $\mathrm{P}_{\text {BcaprE }}$ & $\begin{array}{l}\text { This } \\
\text { study }\end{array}$ & $103.5 \pm 4.2$ \\
\hline pSG-P/luxS & pSG-pro-NK with promoter $\mathrm{P}_{\text {luxS }}$ & $\begin{array}{l}\text { This } \\
\text { study }\end{array}$ & $99.2 \pm 3.8$ \\
\hline pSG-P gsiB & pSG-pro-NK with promoter $\mathrm{P}_{g \text { siB }}$ & $\begin{array}{l}\text { This } \\
\text { study }\end{array}$ & $44.6 \pm 2.9$ \\
\hline pSG-P ${ }_{y x i E}$ & pSG-pro-NK with promoter $P_{y x i E}$ & $\begin{array}{l}\text { This } \\
\text { study }\end{array}$ & $20.2 \pm 2.0$ \\
\hline pSG-P $P_{43}$ & pSG-pro-NK with promoter $\mathrm{P}_{P 43}$ & $\begin{array}{l}\text { This } \\
\text { study }\end{array}$ & $140.5 \pm 2.5$ \\
\hline pSG-2P gsiB & pSG-pro-NK with promoter $\mathrm{P}_{g s i B^{-}} \mathrm{P}_{g s i B}$ & $\begin{array}{l}\text { This } \\
\text { study }\end{array}$ & $48.0 \pm 2.2$ \\
\hline pSG-2P BcaprE & pSG-pro-NK with promoter $P_{\text {BcaprE }}-P_{\text {BcaprE }}$ & $\begin{array}{l}\text { This } \\
\text { study }\end{array}$ & $120.3 \pm 2.4$ \\
\hline pSG-2P $P_{\text {Hpall }}$ & pSG-pro-NK with promoter $P_{\text {Hpalr }} P_{\text {Hpall }}$ & $\begin{array}{l}\text { This } \\
\text { study }\end{array}$ & $199.4 \pm 7.1$ \\
\hline pSG-2P $P_{43}$ & pSG-pro-NK with promoter $\mathrm{P}_{P_{43}}-\mathrm{P}_{P 43}$ & $\begin{array}{l}\text { This } \\
\text { study }\end{array}$ & $157.2 \pm 4.0$ \\
\hline pSG-P $P_{\text {P43 }}-P_{\text {Hpall }}$ & pSG-pro-NK with promoter $\mathrm{P}_{\mathrm{P43}}-\mathrm{P}_{\text {Hpall }}$ & $\begin{array}{l}\text { This } \\
\text { study }\end{array}$ & $231.7 \pm 6.0$ \\
\hline pSG-P $P_{\text {Hpall }}-P_{P 43}$ & pSG-pro-NK with promoter $\mathrm{P}_{\text {Hpall }} \mathrm{P}_{P 43}$ & $\begin{array}{l}\text { This } \\
\text { study }\end{array}$ & $210.6 \pm 5.2$ \\
\hline pSG-P $P_{\text {BcaprE }}-P_{\text {Hpall }}$ & pSG-pro-NK with promoter $\mathrm{P}_{\text {BcaprE }} \mathrm{P}_{\text {Hpall }}$ & $\begin{array}{l}\text { This } \\
\text { study }\end{array}$ & $175.5 \pm 5.0$ \\
\hline pSG-P $P_{\text {Hpall }}-P_{\text {BcaprE }}$ & pSG-pro-NK with promoter $\mathrm{P}_{\text {Hpall }} \mathrm{P}_{\text {BcaprE }}$ & $\begin{array}{l}\text { This } \\
\text { study }\end{array}$ & 0 \\
\hline pSG-P $P_{y \times i}-P_{\text {Hpall }}$ & pSG-pro-NK with promoter $P_{y x i E}-P_{\text {Hpall }}$ & $\begin{array}{l}\text { This } \\
\text { study }\end{array}$ & 0 \\
\hline pSG-P Hpall $P_{y x i E}$ & pSG-pro-NK with promoter $P_{\text {Hpall }} P_{y x i E}$ & $\begin{array}{l}\text { This } \\
\text { study }\end{array}$ & $166.7 \pm 2.5$ \\
\hline pSG-P $P_{\text {siB }}-P_{\text {Hpall }}$ & pSG-pro-NK with promoter $\mathrm{P}_{\text {gsib }}-\mathrm{P}_{\text {Hpall }}$ & $\begin{array}{l}\text { This } \\
\text { study }\end{array}$ & $164.9 \pm 3.0$ \\
\hline pSG-P $P_{\text {Hpall }}-P_{\text {gsiB }}$ & pSG-pro-NK with promoter $P_{\text {Hpall }} P_{\text {gsiB }}$ & $\begin{array}{l}\text { This } \\
\text { study }\end{array}$ & 0 \\
\hline pSG-P/uxS $-P_{\text {Hpall }}$ & pSG-pro-NK with promoter $\mathrm{P}_{\text {luxS }}-\mathrm{P}_{\text {Hpall }}$ & $\begin{array}{l}\text { This } \\
\text { study }\end{array}$ & $77.5 \pm 4.0$ \\
\hline pSG-P $P_{\text {Hpall }}-P_{\text {luxS }}$ & pSG-pro-NK with promoter $\mathrm{P}_{\text {Hpall }} \mathrm{P}_{\text {luxS }}$ & $\begin{array}{l}\text { This } \\
\text { study }\end{array}$ & 0 \\
\hline pSG-3P Hpall & pSG-pro-NK with promoter $\mathrm{P}_{\text {Hpall }} \mathrm{P}_{\text {Hpall }} \mathrm{P}_{\text {Hpall }}$ & $\begin{array}{l}\text { This } \\
\text { study }\end{array}$ & $213.3 \pm 4.1$ \\
\hline pSG-3P $P_{43}$ & pSG-pro-NK with promoter $\mathrm{P}_{P_{43}}-\mathrm{P}_{P_{43}}-\mathrm{P}_{P_{43}}$ & $\begin{array}{l}\text { This } \\
\text { study }\end{array}$ & $219.2 \pm 7.7$ \\
\hline pSG-2P $P_{\text {Hpall }} P_{P_{43}}$ & pSG-pro-NK with promoter $\mathrm{P}_{\text {Hpall }} \mathrm{P}_{\text {Hpall }} \mathrm{P}_{P_{43}}$ & This & $264.2 \pm 7.0$ \\
\hline
\end{tabular}


Table 1 Strains and plasmids used in this study (Continued)

\begin{tabular}{|c|c|c|c|}
\hline Strains or plasmids & Description & Source & $\begin{array}{l}\text { Highest yield of NK (U/ } \\
\mathrm{mL})\end{array}$ \\
\hline & & study & \\
\hline pSG-P $P_{443}-2 P_{\text {Hpalll }}$ & pSG-pro-NK with promoter $\mathrm{P}_{\mathrm{P}_{43}}-\mathrm{P}_{\text {Hpall }}-\mathrm{P}_{\text {Hpall }}$ & $\begin{array}{l}\text { This } \\
\text { study }\end{array}$ & $47.5 \pm 3.1$ \\
\hline pSG-P Hpall $2 \mathrm{P}_{\text {P43 }}$ & pSG-pro-NK with promoter $\mathrm{P}_{H p a l l} \mathrm{P}_{P_{43}}-\mathrm{P}_{P_{43}}$ & $\begin{array}{l}\text { This } \\
\text { study }\end{array}$ & $199.4 \pm 7.1$ \\
\hline pSG-2P $P_{43}-P_{\text {Hpall }}$ & pSG-pro-NK with promoter $\mathrm{P}_{\mathrm{P}_{3}}-\mathrm{P}_{\mathrm{P43}}-\mathrm{P}_{\text {Hpall }}$ & $\begin{array}{l}\text { This } \\
\text { study }\end{array}$ & $149.4 \pm 5.0$ \\
\hline pSG-P $P_{\text {Hpall }}-P_{P 43}-P_{\text {Hpall }}$ & pSG-pro-NK with promoter $\mathrm{P}_{\text {Hpall }}-\mathrm{P}_{\mathrm{P}_{43}}-\mathrm{P}_{\text {Hpall }}$ & $\begin{array}{l}\text { This } \\
\text { study }\end{array}$ & $206.3 \pm 7.0$ \\
\hline pSG-P $P_{P 43}-P_{H p a l l}-P_{P 43}$ & pSG-pro-NK with promoter $\mathrm{P}_{P 43}-\mathrm{P}_{\text {Hpall }}-\mathrm{P}_{P 43}$ & $\begin{array}{l}\text { This } \\
\text { study }\end{array}$ & $182.3 \pm 5.6$ \\
\hline pSG-4P Hpall & pSG-pro-NK with promoter $\mathrm{P}_{\text {Hpall }} \mathrm{P}_{\text {Hpall }} \mathrm{P}_{\text {Hpall }}-\mathrm{P}_{\text {Hpall }}$ & $\begin{array}{l}\text { This } \\
\text { study }\end{array}$ & $200.0 \pm 2.6$ \\
\hline pSG-4P $P_{P 43}$ & pSG-pro-NK with promoter $\mathrm{P}_{P_{43}}-\mathrm{P}_{P_{43}}-\mathrm{P}_{P_{43}}-\mathrm{P}_{P_{43}}$ & $\begin{array}{l}\text { This } \\
\text { study }\end{array}$ & $222.9 \pm 4.8$ \\
\hline pSG- $2 \mathrm{CP}_{\text {BcaprE }}$ & pSG-pro-NK with promoter $\mathrm{CP}_{\text {BcaprE }} \mathrm{P}_{\text {BcaprE }}$ & $\begin{array}{l}\text { This } \\
\text { study }\end{array}$ & $120.3 \pm 2.4$ \\
\hline pSG-2CP Hpall & pSG-pro-NK with promoter $\mathrm{CP}_{\text {Hpall }}-\mathrm{P}_{\text {Hpall }}$ & $\begin{array}{l}\text { This } \\
\text { study }\end{array}$ & $200.8 \pm 4.6$ \\
\hline pSG-3CP Hpall & pSG-pro-NK with promoter $\mathrm{CP}_{\text {Hpall }}-\mathrm{CP}_{\text {Hpall }} \mathrm{P}_{\text {Hpall }}$ & $\begin{array}{l}\text { This } \\
\text { study }\end{array}$ & $138.3 \pm 3.8$ \\
\hline pSG-2CP $P_{p 43}$ & pSG-pro-NK with promoter $\mathrm{CP}_{P_{43}}-\mathrm{P}_{P_{43}}$ & $\begin{array}{l}\text { This } \\
\text { study }\end{array}$ & $166.7 \pm 5.3$ \\
\hline pSG-3CP $P_{P 43}$ & pSG-pro-NK with promoter $\mathrm{CP}_{P_{43}}-\mathrm{CP}_{P_{43}}-\mathrm{P}_{P_{43}}$ & $\begin{array}{l}\text { This } \\
\text { study }\end{array}$ & $181.7 \pm 6.3$ \\
\hline pSG-4CP $P_{43}$ & pSG-pro-NK with promoter $\mathrm{CP}_{\mathrm{P}_{43}}-\mathrm{CP}_{\mathrm{P}_{43}}-\mathrm{CP}_{\mathrm{P}_{43}}-\mathrm{P}_{\mathrm{P}_{43}}$ & $\begin{array}{l}\text { This } \\
\text { study }\end{array}$ & $231.7 \pm 8.0$ \\
\hline pSG-5CP ${ }_{p 43}$ & pSG-pro-NK with promoter $\mathrm{CP}_{P_{43}}-\mathrm{CP}_{P_{43}}-\mathrm{CP}_{P_{43}}-\mathrm{CP}_{P_{43}}-\mathrm{P}_{P_{43}}$ & $\begin{array}{l}\text { This } \\
\text { study }\end{array}$ & $254.2 \pm 5.1$ \\
\hline
\end{tabular}

Note: The corresponding highest yield of NK for each construct was detected using the 36-h supernatant

second highest expression of $210.6 \pm 5.2 \mathrm{FU} / \mathrm{ml}$. The result of the SDS-PAGE analysis (Fig. 3b) was supported by the above results of the fibrinolytic activity. These results showed that NK expression levels under the control of these double promoters were clearly different from each other.

\section{Effects of different triple-promoters on the nattokinase expression}

Analysis of NK production showed that promoters $\mathrm{P}_{\text {HpaII }}$ and $\mathrm{P}_{P 43}$ could efficiently promote the expression of NK. To further improve NK production, the expression profiles of eight recombinant strains with three tandem promoters were determined by enzymatic activities and SDS-PAGE (Fig. 4). As shown in Fig. 4a, the NK expression mediated by pSG- $\mathrm{P}_{\text {HpaII }}-\mathrm{P}_{\text {HpaII }}-\mathrm{P}_{\text {P43 }}$ reached the highest activity, $264.2 \pm 7.0 \mathrm{FU} / \mathrm{ml}$, which was $14 \%$ higher than that under the control of the dual-promoter $\mathrm{P}_{\text {P43 }}-\mathrm{P}_{\text {HpaII }}$. The triple-promoters $\mathrm{P}_{\text {HpaII }}-\mathrm{P}_{\text {P43 }}-\mathrm{P}_{\text {HpaII }}(206.3$ $\pm 7.0 \mathrm{FU} / \mathrm{ml})$ and $\mathrm{P}_{P 43}-\mathrm{P}_{\text {HpaII }}-\mathrm{P}_{P 43}(182.3 \pm 5.6 \mathrm{FU} / \mathrm{ml})$ showed similar promoter strengths, and the production that was promoted by both improved considerably compared with the production of $\mathrm{P}_{\text {HpaII }}$ and $\mathrm{P}_{P 43}$. In contrast, $\mathrm{P}_{\text {P43 }}-\mathrm{P}_{\text {HpaII }} \mathrm{P}_{\text {HpaII }}(47.5 \pm 3.1 \mathrm{FU} / \mathrm{ml})$ did not exhibit an efficient expression of $\mathrm{NK}$, and $\mathrm{P}_{\text {HpaII }}-\mathrm{P}_{P 43}-\mathrm{P}_{P 43}(0 \mathrm{FU} / \mathrm{ml})$ exhibited no expression of NK. These results indicated that the arrangement of the promoters in tandem has intrinsic effects on the expression level of the target protein.

The NK production of the strain harboring pSG$\mathrm{P}_{\text {HpaII }}-\mathrm{P}_{\text {HpaII }} \mathrm{P}_{\text {HpaII }}(213.3 \pm 5.1 \mathrm{FU} / \mathrm{ml})$ was increased by 92.2\% compared with that under the control of pSG-P $\mathrm{P}_{\text {HpaII }}$, and by $7 \%$ compared with that under the control of pSG- $\mathrm{P}_{\text {HpaII }} \mathrm{P}_{\text {HpaII. }}$. Furthermore, pSG- $\mathrm{P}_{P 43}-\mathrm{P}_{P 43}-\mathrm{P}_{P 43}(219.2$ $\pm 7.7 \mathrm{FU} / \mathrm{ml}$ ) enhanced the NK production by $55.9 \%$ compared with pSG- $\mathrm{P}_{P 43}$, and $39.4 \%$ compared with pSG $-\mathrm{P}_{P 43}-\mathrm{P}_{P 43}$. The above results of the fibrinolytic activity assays were consistent with those of SDS-PAGE analysis (Fig. 4b).

As the number of promoters increased, the level of NK expression was enhanced up to the triple-promoter. Therefore, we constructed quad-promoter systems, $\mathrm{P}_{P 43^{-}}$ 
a

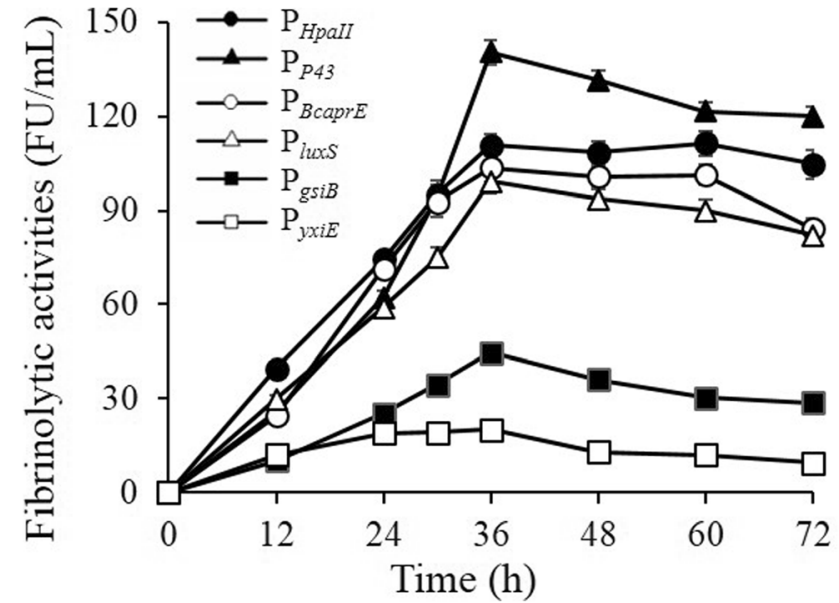

b

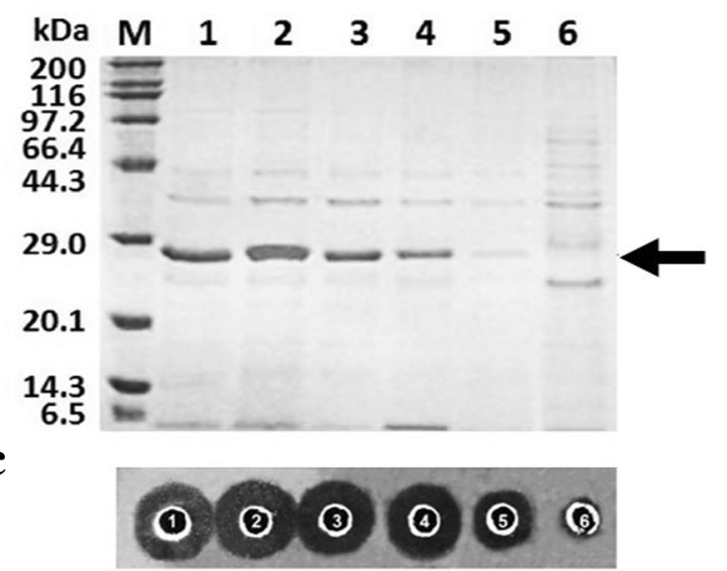

Fig. 2 Effects of different single promoters on the overexpression of NK. (a) Fibrinolytic activities of NK in the supernatant. The recombinant strains having different single promotes were cultured in TB medium for $72 \mathrm{~h}$ with periodical sampling. $\mathbf{b}$ SDS-PAGE analysis. Recombinant strains having different single promoters were cultured in the TB medium for $36 \mathrm{~h}$, and then the cells and the supernatant culture were separated by centrifugation. Supernatant $(15 \mu \mathrm{L})$ was loaded into each lane. Lane M: standard marker proteins; Lane 1-6: $\mathrm{P}_{\text {Hpalli }} \mathrm{P}_{\text {P43; }} \mathrm{P}_{\text {BcaprEi }} \mathrm{P}_{\text {luxs; }} \mathrm{P}_{\text {gsiB }}$ and $\mathrm{P}_{\text {yxiE. }}$. The arrow indicates that the NK bands correspond to 36-h supernatant. c Fibrin plate analysis. Transparent zones produced by the enzyme activity of NK and its variants in the supernatant, which was induced for $36 \mathrm{~h}$, were examined by the fibrin plate method, which was conducted at $37^{\circ} \mathrm{C}$ for 4 h. 1-6: $\mathrm{P}_{\text {Hpalli }} \mathrm{P}_{\text {P43; }} \mathrm{P}_{\text {Bcaprei }} \mathrm{P}_{\text {lux }} \mathrm{P}_{\mathrm{g} \text { giB }}$ and $\mathrm{P}_{\text {yxiE }}$

$\mathrm{P}_{\text {P43 }}-\mathrm{P}_{\text {P43 }}-\mathrm{P}_{P 43}$ and $\mathrm{P}_{\text {HpaII }}-\mathrm{P}_{\text {HpaII }}-\mathrm{P}_{\text {HpaII }}-\mathrm{P}_{\text {HpaII }}$, to test whether the enhancement of NK expression would continue by increasing repetitive promoters. The results in Table 2 showed that the NK activity in the supernatant induced by $\mathrm{P}_{\text {HpaII }}-\mathrm{P}_{\text {HpaII }}-\mathrm{P}_{\text {HpaII }}-\mathrm{P}_{\text {HpaII }}$ decreased slightly. Moreover, the NK production mediated by $\mathrm{P}_{P 43}-\mathrm{P}_{P 43}-\mathrm{P}_{P 43}-\mathrm{P}_{P 43}$ was almost as same as that mediated by $\mathrm{P}_{P 43}-\mathrm{P}_{P 43}-\mathrm{P}_{P 43}$. These results documented that the expression level of the target protein will not increase unconditionally with the increase in the number of promoters $\mathrm{P}_{P 43}$ or $\mathrm{P}_{\text {HpaII }}$.

\section{Nattokinase expression mediated by core region of $\mathbf{P}_{\mathrm{Hpall}}$ and $\mathrm{P}_{\mathrm{P}_{43}}$ in tandem repeats}

These two promoters, $\mathrm{P}_{P 43}$ and $\mathrm{P}_{\text {HpaII }}$, had strong abilities to overexpress the recombinant NK in B. subtilis WB800. Considering that the length of the promoter affects its expression activity, plasmids harboring the core region of $\mathrm{P}_{P 43}$ or $\mathrm{P}_{\text {HpaII }}$ in tandem repeats $\left(\mathrm{pSG}-\mathrm{nCP}_{\mathrm{X}}\right.$ ) were constructed, as shown in Fig. 1c. The NK expression activity of plasmids $\mathrm{pSG}-\mathrm{nCP}_{\mathrm{X}}$ was determined by the fibrinolytic activity and SDS-PAGE analysis (Fig. 5).

As shown in Fig. $5 \mathrm{a}$, the NK production of the strain harboring pSG-2CP $\mathrm{CPaII}_{\text {H }}(200.8 .2 \pm 4.6 \mathrm{FU} / \mathrm{ml})$ was increased by $81.2 \%$ compared with pSG-P $\mathrm{P}_{\text {HpaII }}$. However, the $\mathrm{NK}$ production promoted by $3 \mathrm{CP}_{\text {HpaII }}(138.3 \pm 3.8$ $\mathrm{FU} / \mathrm{ml}$ ) decreased by $31.1 \%$ compared with that promoted by $2 \mathrm{CP}_{\text {HpaII }}$. It could be seen that the NK expression that was mediated by pSG-5CP ${ }_{P 43}(254.2 \pm 5.1 \mathrm{FU} /$ $\mathrm{ml}$ ) was $80.9 \%$ higher than that mediated by $\mathrm{pSG}-\mathrm{P}_{P 43}$.
The expression level of NK increased with the increase in the number of core regions of $\mathrm{P}_{P 43}$ up to five. The SDS-PAGE analysis showed that the NK expressive quantity in the supernatant produced by $\mathrm{pSG}-\mathrm{nCP}_{\text {HpaII }}$ (Fig. 5b) and pSG-nCP ${ }_{P 43}$ (Fig. 5c) was consistent with the results of the NK activity assay. These results suggested that the core regions of $\mathrm{P}_{P 43}$ and $\mathrm{P}_{\text {HpaII }}$ could produce and enhance the expression level of NK efficiently.

Scale-up expression of nattokinase in a 5-L fermenter using the strain harboring $p S G-P_{H p a l l}-P_{H p a l l}-P_{P 43}$ Our results indicated that the highest overexpression level of NK was produced by the triple-promoter $\mathrm{P}_{\text {HpaII }}-\mathrm{P}_{H-}$ paII $-\mathrm{P}_{P 43}$. Based on the results of the optimization of the cultivation conditions in shaking flask experiments (data not shown), the scale-up of recombinant NK production was completed in a 5-L fermenter using the strain harboring pSG- $\mathrm{P}_{\text {HpaII }}-\mathrm{P}_{\text {HpaII }}-\mathrm{P}_{\text {P43 }}$. The process for the cultivation in the fermenter is shown in Fig. 6. The cell density reached the highest $\mathrm{OD}_{600}$ value of $33.0 \pm 0.4$ at $20 \mathrm{~h}$. Similar to the cell growth, NK production was significantly increased and reached the highest value of $816.7 \pm$ $30.0 \mathrm{FU} / \mathrm{ml}$ at $20 \mathrm{~h}$, which was the highest value ever reported. NK production was about two-fold higher in the 5-L fermenter compared to that of the shaking flask experiments. These results indicated that the strain harboring pSG- $\mathrm{P}_{\text {HpaII }}-\mathrm{P}_{\text {HpaII }}-\mathrm{P}_{\text {P43 }}$ had great potential for the industrial production of $\mathrm{NK}$. 


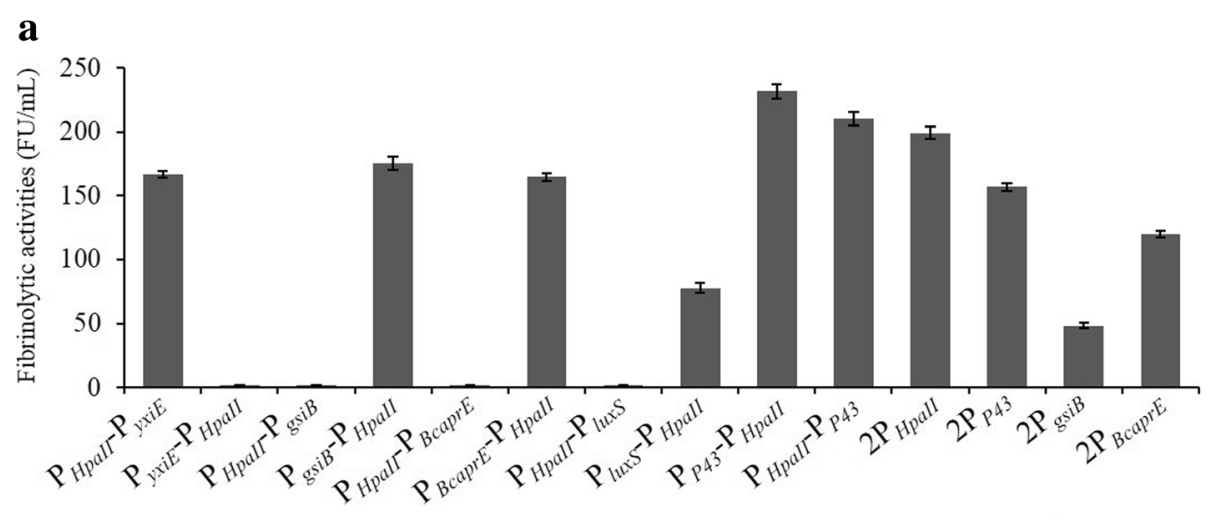

b

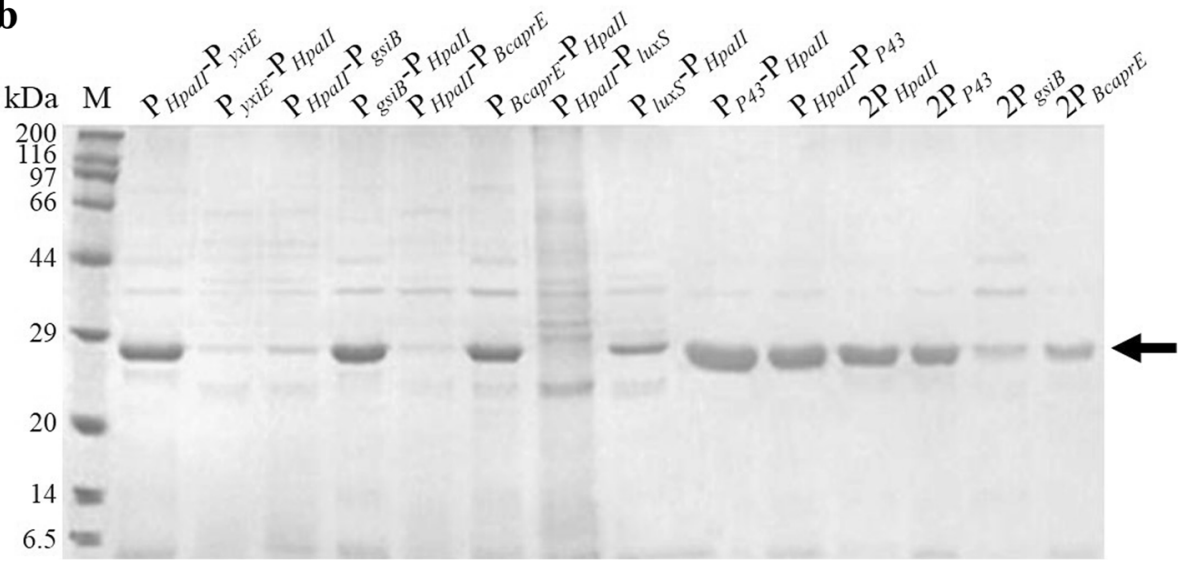

Fig. 3 Overproduction of NK under the control of the dual-promoter systems. a Fibrinolytic activities of NK in the supernatant. $\mathbf{b}$ SDS-PAGE analysis. Lane M: standard marker proteins. The position of the NK protein bands is indicated by an arrow. Recombinant strains having different dual-promotes were cultured in the TB medium for $36 \mathrm{~h}$, and then the cells and the supernatant culture were separated by centrifugation

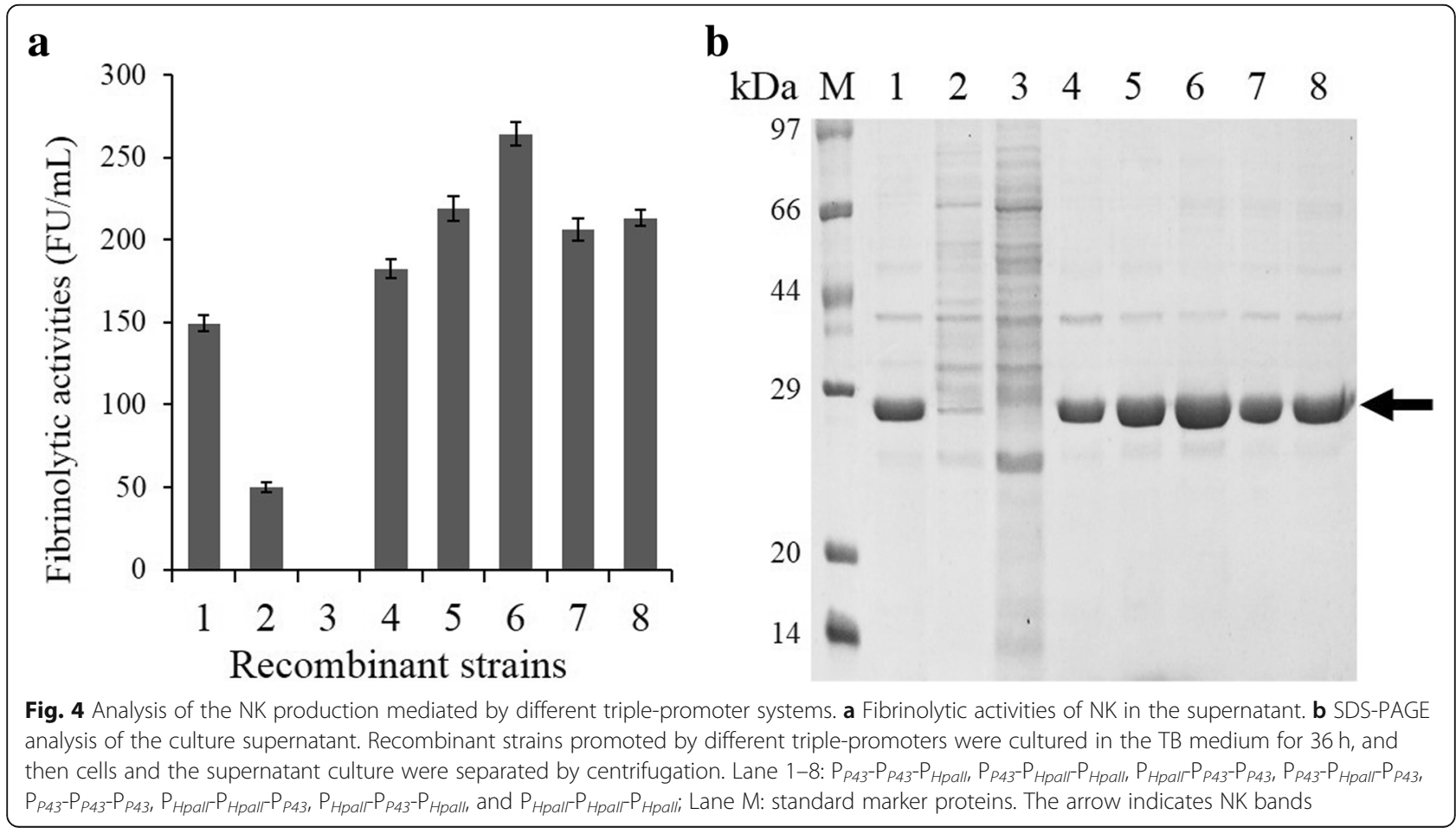


Table 2 Nattokinase yield under the control of tandem repeats containing whole sequence or core region of $P_{H p a l l}$ and $P_{P 43}$

\begin{tabular}{|c|c|c|c|c|c|}
\hline \multirow{2}{*}{$\begin{array}{l}\text { Single } \\
\text { Promoter }\end{array}$} & \multicolumn{2}{|c|}{$\begin{array}{l}\text { Whole promoter region } \\
\text { in tandem }\end{array}$} & \multicolumn{3}{|c|}{$\begin{array}{l}\text { Core promoter region } \\
\text { in tandem }\end{array}$} \\
\hline & Activity (FU/mL) & Promoter & Activity (FU/mL) & Promoter & Activity $(\mathrm{FU} / \mathrm{mL})$ \\
\hline \multirow[t]{3}{*}{$P_{\text {Hpall }}$} & $110.8 \pm 5.2$ & $2 \mathrm{P}_{\text {Hpall }}$ & $199.4 \pm 7.1$ & $2 \mathrm{CP}_{\text {Hpall }}$ & $200.8 \pm 4.6$ \\
\hline & & $3 \mathrm{P}_{\text {Hpall }}$ & $213.3 \pm 4.1$ & $3 C P_{\text {Hpall }}$ & $138.3 \pm 3.8$ \\
\hline & & $4 \mathrm{P}_{\text {Hpall }}$ & $200.0 \pm 2.6$ & & \\
\hline \multirow[t]{4}{*}{$P_{P 43}$} & $140.5 \pm 2.5$ & $2 \mathrm{P}_{P_{43}}$ & $157.2 \pm 4.0$ & $2 \mathrm{CP}_{P 43}$ & $166.7 \pm 5.3$ \\
\hline & & $3 P_{P 43}$ & $219.2 \pm 7.7$ & $3 C_{P 43}$ & $181.7 \pm 6.3$ \\
\hline & & $4 \mathrm{P}_{P_{43}}$ & $222.9 \pm 4.8$ & $4 C P_{P_{43}}$ & $231.7 \pm 8.0$ \\
\hline & & & & $5 C_{P 43}$ & $254.2 \pm 5.1$ \\
\hline
\end{tabular}

\section{Discussion}

Six promoters having high expression strength were selected to overexpress the NK enzyme in B. subtilis WB800, and the overexpression of NK mediated by those single promoter systems exhibited significantly different levels. In our study, the highest expression level of NK driven by a single promoter was $140.5 \pm 3.9 \mathrm{FU} / \mathrm{ml}$ as induced by $\mathrm{P}_{P 43}$.
The order of the strength of the six single promoters mediating NK expression in B. subtilis was $\mathrm{P}_{\text {P43 }}>\mathrm{P}_{\text {HpaII }}>$

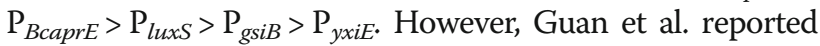
that the activity of the single promoter $\mathrm{P}_{P 43}$ was lower than that of $\mathrm{P}_{l u x S}$ and $\mathrm{P}_{y x i E}$ for aminopeptidase expression in $B$. subtilis [31]. In addition, Zhang et al. reported that $\mathrm{P}_{y x i E}$ exhibited higher expression strengths than $\mathrm{P}_{P 43}$, both in $B$.

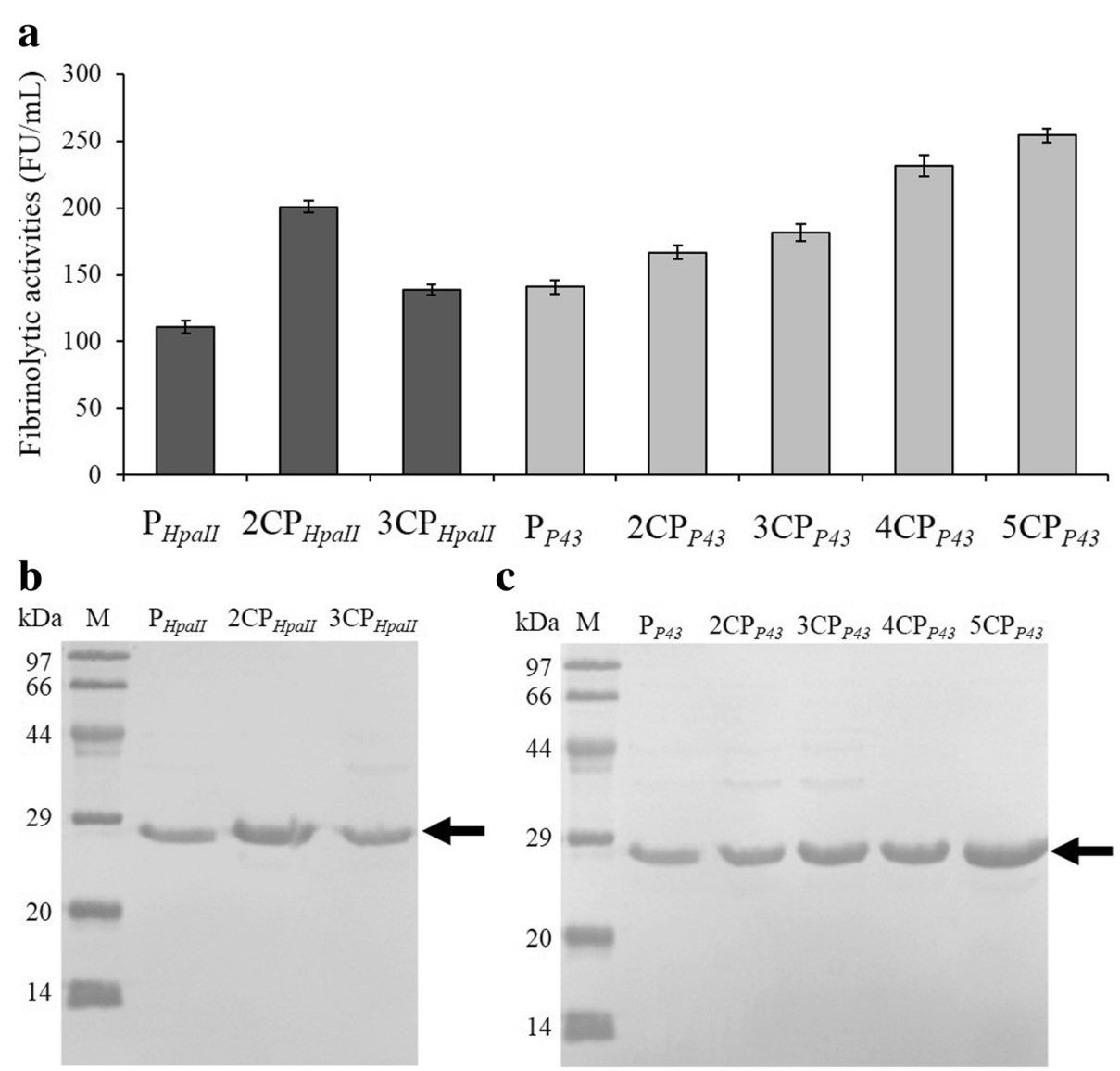

Fig. 5 Effects of the multi core regions of $\mathrm{P}_{H p a l l}$ and $\mathrm{P}_{P_{43}}$ in tandem on NK production. a The fibrinolytic activities of NK in the supernatant. Recombinant strains harboring promoters of repetitive core regions were cultured in TB medium for $36 \mathrm{~h}$, and then cells and the supernatant culture were separated by centrifugation. The SDS-PAGE analysis of the NK expression mediated by the repetitive core regions of $\mathrm{P}_{\text {Hpall }}(\mathbf{b})$ and $P_{P 43}$ (c). The arrow indicates the NK bands corresponding to the 36 -h supernatant, and $15 \mu \mathrm{L}$ supernatant was loaded into each lane 


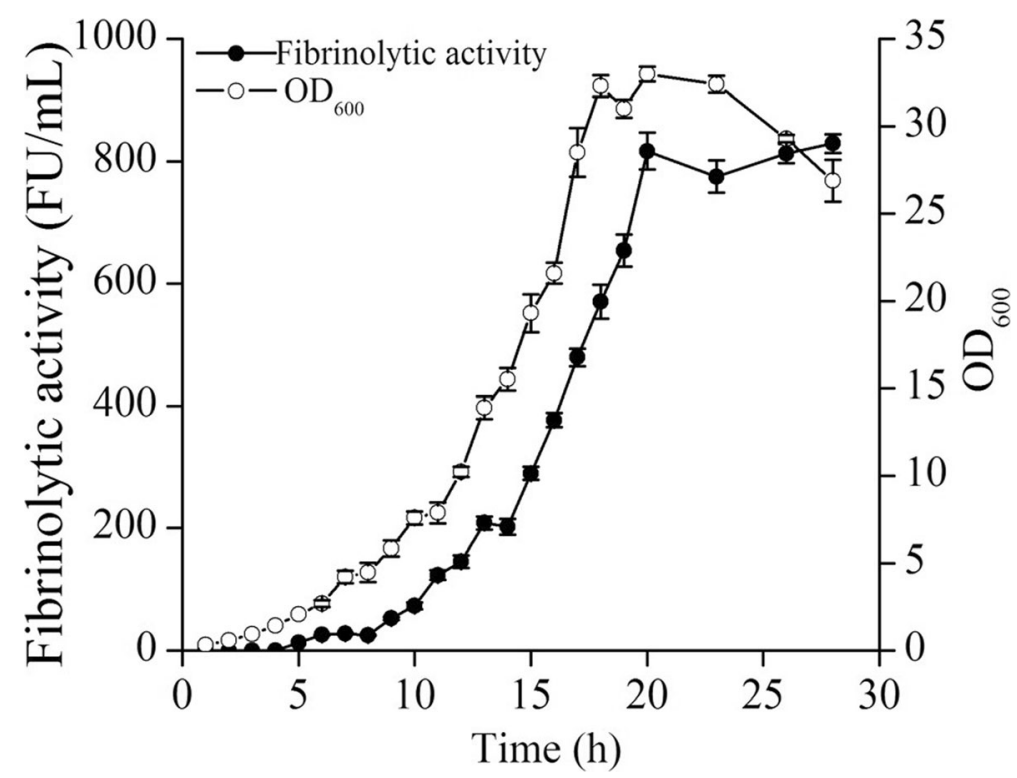

Fig. 6 Analysis of fermentation of NK in the recombinant strain harboring PSG-P $\mathrm{P}_{\text {Hpall }} \mathrm{P}_{\text {Hpall }}-\mathrm{P}_{\mathrm{P} 43}$. The fermentation was carried out in a 5-L fermenter, and the cell growth and NK activity were measured by taking a sample every $2 \mathrm{~h}$

subtilis and E. coli [23]. The expression level of the target gene is naturally determined by the promoter, signal peptide and host, and many studies have suggested that the effect of the promoter strength on the heterologous expression varies. Our results are consistent with the effect of a promoter varying with the change in the target gene [34]. The growth curves of strains containing a single promoter were approximately same (Additional file 1: Figure S1), and this result confirmed that the expression cassettes with different promoters, not the cell amount, caused the different expression levels of NK.

The NK expression level driven by a dual-promoter $\mathrm{P}_{P 43}-\mathrm{P}_{P 43}$ reached $157.2 \pm 3.0 \mathrm{FU} / \mathrm{ml}$, which was $10 \%$ higher than that induced by the single promoter $\mathrm{P}_{P 43}$. Similar results were observed between the dual-promoter $\mathrm{P}_{\text {BcaprE }}-\mathrm{P}_{\text {BcaprE }}$ and the single promoter $\mathrm{P}_{\text {BcaprE }}$ and the dual-promoter $\mathrm{P}_{g s i B}-\mathrm{P}_{g s i B}$ and the single promoter $\mathrm{P}_{g s i B}$. However, the strength of the dual-promoter containing two $\mathrm{P}_{\text {HpaII }}$ was 1.8-fold higher than that of the single promoter. The two promoters $\mathrm{P}_{P 43}$ and $\mathrm{P}_{\text {HpaII }}$ exhibited higher promoter activity for NK expression than that of the other promoters. We further carried out the experiments of arranging $\mathrm{P}_{\text {HpaII }}$ and $\mathrm{P}_{P 43}$ by combining three or four promoters in tandem. As shown in Table 2, our results indicated that the NK expression level was not associated with the numbers of tandem repeats of the promoters. The NK production under the control of $\mathrm{P}_{P 43^{-}}$ $\mathrm{P}_{P 43}$ was increased by $11.9 \%$ compared with that promoted by $\mathrm{P}_{P 43}$, and the $\mathrm{NK}$ production mediated by $\mathrm{P}_{P 43}-\mathrm{P}_{P 43}-\mathrm{P}_{P 43}$ increased by $39.4 \%$ compared with that promoted by $\mathrm{P}_{P 43}-\mathrm{P}_{P 43}$. However, the NK expression level increased by only $1.7 \%$ when promoted by $\mathrm{P}_{P 43}-\mathrm{P}_{P 43}$
$-\mathrm{P}_{P 43}-\mathrm{P}_{P 43}$. Furthermore, NK production decreased under the control of four $\mathrm{P}_{\text {HpaII }}$ in tandem compared with the expression controlled by three tandem promoters. The results were in agreement with studies that suggested that the length of the promoter affects its expression activity [35]. Although the cooperation mechanism of the tandem promoters was not clear, the increased production of NK suggested that this strategy of gene expression based on tandem promoter is an effective way to improve promoter activity.

The core region of a promoter plays an important role in regulating transcription initiation and is the minimal portion of a promoter that is required to properly initiate transcription [36]. To understand the effect of the length of repetitive whole-sequence promoters containing $\mathrm{P}_{P 43}$ or $\mathrm{P}_{\text {HpaII }}$ in tandem on the expression level of $\mathrm{NK}$, a series of promoters with core-region repeats $\left(\mathrm{nCP}_{P 43}\right.$ and $\left.\mathrm{nCP}_{\text {HpaII }}\right)$ were constructed. The whole sequence of $\mathrm{P}_{\text {HpaII }}$ is $284 \mathrm{bps}$; however, the core-region sequence of $\mathrm{P}_{\text {HpaII }}$ is only $31 \mathrm{bps}$. The NK production mediated by $2 \mathrm{P}_{\text {HpaII }}$ and $2 \mathrm{CP}_{\text {HpaII }}$ almost reached the same level, which suggested that the core region of $\mathrm{P}_{\text {HpaII }}$ could efficiently initiate the $\mathrm{NK}$ overexpression. However, it was unexpected that the strength of $3 \mathrm{CP}_{\text {HpaII }}$ for NK expression was $35.2 \%$ lower than that of $3 \mathrm{P}_{\text {HpaII }}$. Further studies will be needed to explore the difference between the whole sequence and the core regions of $\mathrm{P}_{\text {HpaII }}$ for the level of gene expression. In addition, the whole sequence of $\mathrm{P}_{P 43}$ is $300 \mathrm{bps}$, and the core region of $\mathrm{P}_{P 43}$ is 29 bps. The NK expression mediated by the whole sequence of $\mathrm{P}_{P 43}$ in tandem increased to that mediated by $4 \mathrm{P}_{P 43}$. The NK production that was initiated by core 
promoters of $\mathrm{P}_{P 43}$ in tandem gradually increased as the number of core regions increased. It was found that both strong promoters, $\mathrm{P}_{P 43}$ and $\mathrm{P}_{\text {HpaII }}$, have distinct characterization and differential expressions of NK. The analysis of the expression level of NK induced by more core regions of $\mathrm{P}_{P 43}$ in tandem will be carried out.

Obviously different effects on NK production are caused by different arrangements in the dual-promoter system. The promoter is recognized by the $\sigma$ factor of RNA polymerase to initiate gene transcription. Several $\sigma$ factors have been defined in $B$. subtilis. It has been reported that $\sigma^{\mathrm{A}}$ - and $\sigma^{\mathrm{B}}$-promoters can function cooperatively. The promoter synergism resulting from the double promoters was found only when the $\sigma^{\mathrm{B}}$-promoter was located upstream of the $\sigma^{\mathrm{A}}$-promoter, and the expression level of reporter gene was severely reduced by switching the locations of the $\sigma^{\mathrm{A}}$ - and $\sigma^{\mathrm{B}}$-promoters [37]. Since $\mathrm{P}_{g s i B}$ is $\sigma^{\mathrm{B}}$-dependent (Additional file 1: Table S1), NK production promoted by $\mathrm{P}_{\text {gsiB }}-\mathrm{P}_{\text {HpaII }}(164.9 \pm 3.0$ $\mathrm{FU} / \mathrm{ml})$ compared with that by $\mathrm{P}_{\text {HpaII }}(110.8 \pm 3.6 \mathrm{FU} /$ $\mathrm{ml})$ and that by $\mathrm{P}_{\text {HpaII }}-\mathrm{P}_{\text {gsiB }}(0 \mathrm{FU} / \mathrm{ml})$, suggested that $\mathrm{P}_{\text {HpaII }}$ might be a $\sigma^{\mathrm{B}}$-dependent promoter. Similar phenomena were observed in the results of NK expression mediated by $\mathrm{P}_{\text {BcaprE }}-\mathrm{P}_{\text {HpaII }}(175.5 \pm 5.0 \mathrm{FU} / \mathrm{ml})$ and $\mathrm{P}_{\text {HpaII }} \mathrm{P}_{\text {BcaprE }}(0 \mathrm{FU} / \mathrm{ml})$, by $\mathrm{P}_{\text {luxS }}-\mathrm{P}_{\text {HpaII }}(77.5 \pm 4.0 \mathrm{FU} /$ $\mathrm{ml}$ ) and $\mathrm{P}_{\text {HpaII }}-\mathrm{P}_{\text {luxS }}(0 \mathrm{FU} / \mathrm{ml})$, predicting that $\mathrm{P}_{\text {luxS }}$ and $\mathrm{P}_{\text {BcaprE }}$ are $\sigma^{\mathrm{B}}$-dependent promoters. Whereas $\mathrm{P}_{y x i E}$ is $\sigma^{\mathrm{A}}$-dependent (Additional file 1: Table S1), results of NK production promoted by $\mathrm{P}_{\text {HpaII }}-\mathrm{P}_{y x i E}(166.7 \pm 2.5 \mathrm{FU} / \mathrm{ml})$, compared with that by $\mathrm{P}_{y x i E}-\mathrm{P}_{\text {HpaII }}(0 \mathrm{FU} / \mathrm{ml})$ and that by $\mathrm{P}_{y x i E}(20.2 \pm 2.0 \mathrm{FU} / \mathrm{ml})$, suggested that $\mathrm{P}_{\text {HpaII }}$ might also be recognized by $\sigma^{\mathrm{A}}$ RNA polymerase. Therefore, promoters $\mathrm{P}_{\text {HpaII }}$ and $\mathrm{P}_{P 43}$ might be recognized by both $\sigma^{\mathrm{A}}$ and $\sigma^{\mathrm{B}}$ RNA polymerases. Our results showed that the NK expression that was promoted by the dual-promoter system makes a large difference, which could be due to the synergistic effect of the double promoters.

Studies have shown that triple-promoters could markedly increase the expression level of heterogeneous genes $[29,38]$. We operated by combining both strong promoters in the form of three promoters in tandem. Eight strains harboring a triple-promoter system containing $\mathrm{P}_{\text {HpaII }}$ and $\mathrm{P}_{P 43}$ were generated, from which the NK production showed different levels. Among these 8 strains, one strain harboring the plasmid pSG- $\mathrm{P}_{\text {HpaII }}$ $-\mathrm{P}_{P 43}-\mathrm{P}_{P 43}$ lost the ability to express $\mathrm{NK}$, and one strain harboring the plasmid pSG- $\mathrm{P}_{\text {P43 }}-\mathrm{P}_{\text {HpaII }}-\mathrm{P}_{\text {HpaII }}$ exhibited low activity of $\mathrm{NK}$ expression $(47.5 \pm 3.1 \mathrm{FU} / \mathrm{ml})$. The other six strains harboring the plasmid containing a triple-promoter exhibited relatively high production of the secreted NK, and the NK expression of four strains were higher than $200 \mathrm{FU} / \mathrm{ml}$. The growth curves of strains containing triple-promoters were approximately the same (Additional file 1: Figure S2), and these results confirmed that the expression cassettes, but not the cell numbers, caused the different levels of NK production with different promoters. On account of the RNA polymerase gene transcription mechanism under the promoter action being very complex, the problem of how to produce this synergy has yet to be further studied. In this study, the highest NK production was mediated by a triple-promoter $\mathrm{P}_{\text {HpaII }}-\mathrm{P}_{\text {HpaII }}-\mathrm{P}_{\text {P43 }}$ and achieved $264.2 \pm$ $7.0 \mathrm{FU} / \mathrm{ml}$, which is much higher than that reported in previous studies $[39,40]$. This strain is a potential strain for the industrial production of NK. In addition, the high yield of NK could promote its application in medicine and in supplementary nutrition. A series of plasmids for NK expression in B. subtilis were constructed in this study, and they have great potential to be used for NK expression or the expression of other genes in industrial applications. The results of the various initial activities of multiple tandem promoters for NK expression also provide additional information on the synergistic interaction of promoters.

\section{Conclusions}

In this study, we generated and characterized the secretory expression of NK under the control of different promoters, including six single promoters and a series of promoters with the whole sequence or core regions in tandem. The expression level of NK mediated by one of these different promoters led to a remarkable difference in B. subtilis WB800. Among the six single promoters, NK production mediated by $\mathrm{P}_{\text {HpaII }}$ and $\mathrm{P}_{P 43}$ exhibited a higher level than the others. The arrangement of these promoters in tandem produced various effects on NK expression. We successively used the triple-promoter $\mathrm{P}_{\text {HpaII }}-\mathrm{P}_{\text {HpaII }}-\mathrm{P}_{\text {P43 }}$ to increase the production of $\mathrm{NK}$ to $264.2 \pm 7.0 \mathrm{FU} / \mathrm{ml}$ in B. subtilis WB800, which was the highest expression level ever reported. Our study provided an efficient way to increase NK production in Bacillus subtilis based on tandem promoters.

\section{Materials and methods}

\section{Plasmids, strains and growth conditions}

The plasmid pMA0911-pro-NK, an E. coli/B. subtilis shuttle plasmid with the HpaII promoter and wapA signal peptide, was used to clone and express NK. $E$. coli JM109 served as a host for cloning and plasmid preparation. B. subtilis WB800 is deficient in eight extracellular proteases and was used as a host for the NK expression. Bacillus subtilis 168 (B. subtilis 168) containing the promoter $\left(\mathrm{P}_{P 43}\right)$ was stored in our laboratory. Transformants were selected on LB agar ( $0.5 \%$ yeast extract, $1 \%$ tryptone, $1 \% \mathrm{NaCl}$ and $2 \%$ agar), supplemented with $100 \mu \mathrm{g} / \mathrm{mL}$ ampicillin for $E$. 
coli JM109 or $50 \mu \mathrm{g} / \mathrm{mL}$ kanamycin for B. subtilis WB800. E. coli JM109 was cultivated in LB medium supplemented with $100 \mu \mathrm{g} / \mathrm{mL}$ ampicillin. B. subtilis WB800 was incubated in TB medium $(2.4 \%$ yeast ex-

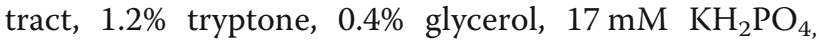
and $72 \mathrm{mM} \mathrm{K} \mathrm{K}_{2} \mathrm{HPO}_{4}$ ) additionally containing $0.02 \%$ $\mathrm{CaCl}_{2}$ and $50 \mu \mathrm{g} / \mathrm{mL}$ kanamycin. All of the strains were cultivated at $37^{\circ} \mathrm{C}$ under shaking conditions at $200 \mathrm{rpm}$. Cell densities were measured using a UV1800/PC spectrophotometer (MAPADA Instrument Co., Ltd., Shanghai, China). Strains and plasmids used in this study are summarized in Table 1.

\section{Construction of recombinant plasmids}

Primers used in this study were synthesized by Shanghai Sangon Biotech Co., Ltd. and are listed in Table 3. A deficiency of the promoter $\mathrm{P}_{\text {HpaII }}$ from the plasmid pMA0911-pro-NK was carried out following megaprimer PCR of the entire plasmid (MEGAWHOP) [41, 42] using primers $\mathrm{P} 0-\mathrm{F}$ and $\mathrm{P} 0-\mathrm{R}$. The PCR product was digested by $D p n \mathrm{I}$, and the resulting plasmid was transformed into JM109 to yield plasmid pSG-pro-NK without a promoter (Table 1).

The promoter $\mathrm{P} 43$ gene was cloned from the genomic DNA of B. subtilis 168 with primers P1 and P2. The amplified product was cloned into pSG-pro-NK by the MEGAWHOP protocol, yielding plasmid pSG $-\mathrm{P}_{P 43}$. The other single promoters $\left(\mathrm{P}_{\text {BcaprE }}, \mathrm{P}_{g s i B}, \mathrm{P}_{y x i E}\right.$ and $\left.\mathrm{P}_{l u x S}\right)$ were synthesized by Shanghai Sangon
Biotech Co., Ltd. and were employed to construct the plasmids pSG-P $\mathrm{P}_{\text {BcaprE }}$, pSG-P $\mathrm{P}_{g s i B}$, pSG-P $\mathrm{P}_{y x i E}$ and pSG$\mathrm{P}_{\text {lux } S}$, respectively, using the same procedures as for pSG-P $P_{P 43}$.

The six single promoters were further employed to construct 14 kinds of expression cassettes under the control of two promoters in tandem. The plasmid pSG $-\mathrm{P}_{\text {P43 }}-\mathrm{P}_{\text {HpaII }}$ was constructed by two steps. The fragment of P43 was amplified from pSG- $\mathrm{P}_{P 43}$ using primers P1 and $\mathrm{P} 11$, and then the $\mathrm{PCR}$ product was inserted upstream of the promoter HpaII in pMA0911-pro-NK following the MEGAWHOP protocol, thereby yielding pSG- $\mathrm{P}_{P 43}-\mathrm{P}_{\text {HpaII }}$. The same procedures were used to construct the other dual-promoter plasmids.

To construct the triple-promoter plasmid pSG-P $\mathrm{HpaII}^{-}$ $\mathrm{P}_{\text {HpaII }}-\mathrm{P}_{P 43}$, the fragment of HpaII was amplified from pMA0911-pro-NK with primers $\mathrm{P} 12$ and $\mathrm{P} 13$ and then was inserted into the front of the promoter $\mathrm{P}_{\text {HpaII }}-\mathrm{P}_{P 43}$ in pSG-P $\mathrm{P}_{\text {HpaII }}-\mathrm{P}_{P 43}$ following the MEGAWHOP protocol. The other triple-promoter plasmids and two quad -promoter plasmids (pSG-4 $\mathrm{P}_{\text {HpaII }}$ and $\mathrm{pSG}-4 \mathrm{P}_{\text {P43 }}$ ) were obtained after being treated in the same manner as for pSG- $\mathrm{P}_{\text {HpaII }}-\mathrm{P}_{\text {HpaII }}-\mathrm{P}_{\text {P43 }}$.

The plasmids pSG- $\mathrm{nCP}_{X}$ harboring the multiple tandem core promoter regions were synthesized by Shanghai RuiDi Biological Technology Co., Ltd. All plasmids were constructed and cloned in E. coli JM109 and were sequenced by Shanghai RuiDi Biological Technology Co., Ltd.

Table 3 Oligodeoxynucleotides used in this study

\begin{tabular}{|c|c|c|}
\hline Primers & Sequence $\left(5^{\prime}-3^{\prime}\right)$ & Description \\
\hline PO-F & GGCAAGGGTTTAAAGGTGGAGATTाTTGAGTGTCGACATGAAAAAAAGAAAGAGGCGAAAC & Upstream for pMA0911-wapA-pro-NK construction \\
\hline PO-R & CCTITIAAAGTTTCGCCTCTTTCTIIIITTCATGTCGACACTCAAAAAATCTCCACCTTTAAACC & $\begin{array}{l}\text { Downstream for pMA0911-wapA-pro-NK } \\
\text { construction }\end{array}$ \\
\hline P1 & GGCAAGGGTTTAAAGGTGGAGATTTTTGAGTTGATAGGTGGTATGTTTCGCTTGAAC & Upstream of $\mathrm{P}_{p 43}$ \\
\hline P2 & CCTITAAAGTTCGCCTCTITCTIITITCATGTCGACGTGTACATTCCTCTCTTACCTATAATGG & Downstream of $\mathrm{P}_{P_{43}}$ \\
\hline P3 & GGCAAGGGTTAAAGGTGGAGATTाTTGAGTTGCCGAATTCCATGAACGAGACTTAAAACG & Upstream of $\mathrm{P}_{\text {BcaprE }}$ \\
\hline P4 & $\begin{array}{l}\text { CCTT } \\
\text { TIAAAGTITCGCCTCTITCTIIIITCATGTCGACTCGGTTCCCTCCTCATIITATACCAACTTG }\end{array}$ & Downstream of $P_{\text {Bcapre }}$ \\
\hline P5 & GGCAAGGGTTAAAGGTGGAGATTITTGAGTGATCGTCACAATGCGCCATCAAACCG & Upstream of $\mathrm{P}_{\text {luxs }}$ \\
\hline P6 & $\begin{array}{l}\text { CCT } \\
\text { TIAAAGTITCGCCTCTITCTIIIITCATGTCGACGGATCCCACTITATGGACGCCGCAGTGTCTG }\end{array}$ & Downstream of $\mathrm{P}_{\text {luxs }}$ \\
\hline P7 & GGCAAGGGTTAAAGGTGGAGATITITGAGTCTATCGAGACACGTTGGCTGG & Upstream of $\mathrm{P}_{g s i B}$ \\
\hline P8 & $\begin{array}{l}\text { CCT } \\
\text { TIAAAGTITCGCCTCTITCTIIIITCATGTCGACTTCCTCCTITAATTGGTGTTGGTTGTTGTATTC }\end{array}$ & Downstream of $\mathrm{P}_{g s i B}$ \\
\hline P9 & GGCAAGGGTTAAAAGGTGGAGATTITTGAGTGATCATTAAATTGAAGCGCGCGAAGC & Upstream of $\mathrm{P}_{y \times i E}$ \\
\hline P10 & $\begin{array}{l}\text { CCT } \\
\text { TTAAAGTTTCGCCTCTTTCTIIIITTCATGTCGACGCTCTTCCCGCCTITCGGACTGTGGGTGG }\end{array}$ & Downstream of $P_{y x i E}$ \\
\hline P11 & GGGACAGGTAGTATTITTGAGAAGATCGTGTACATTCCTCTCTTACCTATAATGG & Downstream for $P_{p_{43}}-P_{\text {Hpall }}$ \\
\hline P12 & GGCAAGGGTTTAAAGGTGGAGATTITTGAGTGATCTTCTCAAAAAATACTACCTGTCCC & Upstream of $\mathrm{P}_{\text {Hpall }}$ \\
\hline P13 & GGGACAGGTAGTATTIITGAGAAGATCTAAATCGCTCCTITTAGGTGGCACAAATGTG & Downstream or $\mathrm{P}_{\text {Hpall }} \mathrm{P}_{\text {Hpall }} \mathrm{P}_{P_{43}}$ \\
\hline
\end{tabular}

Note: Homology arms of targeting vectors for gene insertions were underlined 


\section{Overexpression of the recombinant nattokinase in $B$. subtilis WB800}

Plasmid transformation was carried out according to the method as previously reported [43, 44]. A single colony was inoculated into $10 \mathrm{ml} \mathrm{LB}$ medium (including $50 \mu \mathrm{g}$ / $\mathrm{ml}$ kanamycin) and were grown overnight at $37^{\circ} \mathrm{C}, 200$ rpm. The culture was transferred into $100 \mathrm{mLTB}$ medium as a final $\mathrm{OD}_{600}$ value of $0.2(\mathrm{v} / \mathrm{v})$, and then was cultivated at $37^{\circ} \mathrm{C}$ for $84 \mathrm{~h}$ under a shaking condition at $200 \mathrm{rpm}$ for the expression of NK. The supernatant was collected for the following research by centrifugation $(10,000 \mathrm{rpm}, 5 \mathrm{~min})$ at $4{ }^{\circ} \mathrm{C}$.

\section{Fed-batch cultivation in 5-L fermenter}

Fed-batch cultivations were carried out in a 5 -L bioreactor, and the initial medium was $2 \mathrm{~L}$ ( $2 \%$ glycerol, $2 \%$ soybean peptone, $0.1 \% \mathrm{NaH}_{2} \mathrm{PO}_{4}, 0.2 \% \mathrm{Na}_{2} \mathrm{HPO}_{4}, 0.02 \%$ $\mathrm{CaCl}_{2}$, and $0.05 \% \mathrm{MgSO}_{4}$ ) containing $50 \mu \mathrm{g} / \mathrm{ml}$ kanamycin. The pre-inoculum culture was $50 \mathrm{mLTB}$ medium including $50 \mu \mathrm{g} / \mathrm{mL}$ kanamycin, which was incubated at $37^{\circ} \mathrm{C}$ under a shaking condition at $200 \mathrm{rpm}$. After $12 \mathrm{~h}$, the culture was inoculated into the 5 - $\mathrm{L}$ fermenter. The inoculation volume was $8 \%$. The cultivated condition was maintained at $37^{\circ} \mathrm{C}$, and the dissolved oxygen (DO) was performed above $30 \%$ under the control of the inlet air and the exponential feeding of glycerol and soybean peptone. During the cultivation process, the $\mathrm{pH}$ was controlled at 7.0 through the automatic addition of $50 \%$ ammonium solution. Samples were taken every $2 \mathrm{~h}$.

\section{Fibrin plate analysis}

A qualitative analysis of the fibrinolytic activity was carried out according to the fibrin plate method [45]. In brief, $10 \mathrm{ml}$ agarose solution (1\%) and $10 \mathrm{ml}$ bovine fibrinogen solution $(1.8 \mathrm{mg} / \mathrm{ml}$ in $50 \mathrm{mM}$ Tris- $\mathrm{HCl}$ buffer $)$ were incubated separately at $60{ }^{\circ} \mathrm{C}$, and $10 \mathrm{U}$ thrombin was added into the agarose solution and mixed. The agarose solution and fibrinogen were mixed, and the plate was put at room temperature for $2 \mathrm{~h}$ to form fibrin clots. Holes were made in the fibrin plate, and $40 \mu \mathrm{l}$ enzyme was added in each hole. The fibrin plates were placed at $37^{\circ} \mathrm{C}$ for $4 \mathrm{~h}$ to detect the fibrinolytic activity.

\section{Fibrinolytic activity determination}

The fibrinolytic activity was determined using the method described by the Japan Nattokinase Association (http://j-nattokinase.org/jnka_nk_english.html). In brief, $1.4 \mathrm{~mL}$ Tris- $\mathrm{HCl}(0.05 \mathrm{M}, \mathrm{pH} 8.0)$ and $0.4 \mathrm{~mL}$ fibrinogen solution $(0.72 \%)$ were pre-incubated in a $37^{\circ} \mathrm{C}$ water bath for $5 \mathrm{~min}$. Thereafter, $0.1 \mathrm{~mL}$ thrombin solution was added, followed by the addition of $0.1 \mathrm{~mL}$ diluted sample after $10 \mathrm{~min}$. The mixture was incubated at $37^{\circ} \mathrm{C}$ for an hour. Finally, trichloroacetic acid solution (0.2 M) was added and incubated at $37^{\circ} \mathrm{C}$ for $20 \mathrm{~min}$ to stop the reaction. The supernatant was transferred into a microtest tube after centrifugation $(12,000 \mathrm{rpm}, 10 \mathrm{~min})$, and the absorbance of the supernatant at $275 \mathrm{~nm}$ was read and recorded. One unit (1 FU) was defined as the amount of the enzyme that increased the absorbance of the filtrate at $275 \mathrm{~nm}$ by 0.01 per minute. The analysis of fibrinolytic activity was independently carried out in triplicate, and the data are presented as the mean \pm s.d.

\section{SDS-PAGE analysis}

Samples were incubated at room temperature for $30 \mathrm{~min}$ with $5 \times$ SDS-PAGE loading buffer and protease inhibitor PMSF (phenylmethane sulphonyl fluoride). Then, the samples were heated at $100{ }^{\circ} \mathrm{C}$ for $5 \mathrm{~min}$ and were applied into $12 \%$ SDS-PAGE with $5 \%$ stacking gels. Finally, the gels were stained by Coomassie Blue R-250.

\section{Additional file}

Additional file 1: Table S1 Characterization of single promoters used for the NK production. Figure S1 The growth curves of recombinant strains harboring different plasmids with a single promoter. Figure S2 The growth curves of recombinant strains containing a triple-promoter. (DOCX 297 kb)

\section{Abbreviations}

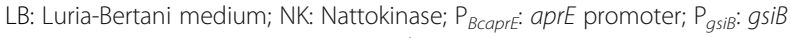
promoter; $\mathrm{P}_{\text {Hpall: }}$ Hpall promoter; $\mathrm{P}_{\text {lux }}$ : luxS promoter; $\mathrm{P}_{\text {P43 }}$ : $\mathrm{P43}$ promoter;

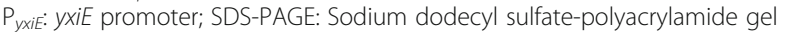
electrophoresis; SP: The wapA signal peptide; TB: Terrific Broth medium

\section{Acknowledgements}

Not applicable.

\section{Funding}

This study was funded by National Key R\&D Program of China (2016YFE0127400), the Fundamental Research Funds for the Central Universities (JUSRP51713B), the national first-class discipline program of Light Industry Technology and Engineering (LITE2018-04), the Priority Academic Program Development of Jiangsu Higher Education Institutions, the 111 Project (No. 111-2-06) and National natural science foundation of China (3140078)

\section{Availability of data and materials}

The authors confirm that all data underlying the findings are fully available without restriction. All relevant data are within the paper and its supplementary information.

\section{Authors' contributions \\ ZL conceived the idea, designed this study, analyzed the data, and was a major contributor in writing the manuscript. WZ participated in revising the manuscript. CG performed the experiments, including construction of plasmids and expression cassettes, overexpression and fermentation, analyzed the data. WC participated in the experiments of constructing expression systems. LZ participated in the fermentation experiment of nattokinase. ZZ conceived of the study, participated in its design, and coordination. All authors have read and approved the final manuscript.}

Ethics approval and consent to participate Not applicable. 


\section{Competing interests}

The authors declare that they have no competing interests.

\section{Publisher's Note}

Springer Nature remains neutral with regard to jurisdictional claims in published maps and institutional affiliations.

\section{Received: 13 August 2018 Accepted: 18 April 2019}

\section{Published online: 07 May 2019}

\section{References}

1. Sumi $H$, Hamada $H$, Tsushima $H$, Mihara $H$, Muraki $H$. A novel fibrinolytic enzyme (nattokinase) in the vegetable cheese Natto; a typical and popular soybean food in the Japanese diet. Experientia. 1987;43(10):1110-1.

2. Fujita M, Nomura K, Hong K, Ito Y, Asada A, Nishimuro S. Purification and characterization of a strong fibrinolytic enzyme (Nattokinase) in the vegetable cheese Natto, a popular soybean fermented food in Japan. Biochem Bioph Res Commun. 1993;197(3):1340-7.

3. Urano T, Ihara H, Umemura K, Suzuki Y, Oike M, Akita S, Tsukamoto Y, Suzuki I, Takada A. The profibrinolytic enzyme subtilisin NAT purified from Bacillus subtilis cleaves and inactivates plasminogen activator inhibitor type 1. J Biol Chem. 2001:276(27):24690-6.

4. Fujita M, Hong KS, Ito Y, Fujii R, Kariya K, Nishimuro S. Thrombolytic effect of Nattokinase on a chemically-induced thrombosis model in rat. Biol Pharm Bull. 1995;18(10):1387-91.

5. Sumi $\mathrm{H}$, Hamada $\mathrm{H}$, Nakanishi $\mathrm{K}$, Hiratani $\mathrm{H}$. Enhancement of the fibrinolytic activity in plasma by oral administration of nattokinase. Acta Haematol. 1990;84(3):139-43.

6. Nakamura T, Yamagata Y, Ichishima E. Nucleotide sequence of the Subtilisin NAT gene, aprN, of Bacillus subtilis (natto). Biosci Biotechnol Biochem. 1992; 56(11):1869-71.

7. Yanagisawa Y, Chatake T, Chiba-Kamoshida K, Naito S, Ohsugi T, Sumi H, Yasuda I, Morimoto Y. Purification,crystallization and preliminary X-ray diffraction experiment of nattokinase from Bacillus subtilis natto. Acta Crystallogr F Struct Biol Commun. 2010;66(12):1670-3.

8. Cai Y, Bao W, Jiang S, Weng M, Jia Y, Yin Y, Zheng Z, Zou G. Directed evolution improves the fibrinolytic activity of nattokinase from Bacillus natto. FEMS Microbiol Lett. 2011;325(2):155-61.

9. Unrean P, Nguyen N. Metabolic pathway analysis and kinetic studies for production of nattokinase in Bacillus subtilis. Bioprocess Biosyst Eng 2013;36:45-56.

10. Zheng ZL, Ye MQ, Zuo ZY, Liu ZG, Tai KC, Zou GL. Probing the importance of hydrogen bonds in the active site of the subtilisin nattokinase by sitedirected mutagenesis and molecular dynamics simulation. Biochem J. 2006; 395(3):509-15.

11. Dabbagh F, Negahdaripour M, Berenjian A, Behfar A, Mohammadi F, Zamani M, Irajie C, Ghasemi Y. Nattokinase: production and application. Appl Microbiol Biotechnol. 2014;98(22):9199-206.

12. Nagarajan V. System for secretion of heterologous proteins in Bacillus subtilis. Methods Enzymol. 1990;185:214-23.

13. Wright AV, Leuschner RGK, Robinson TP, Hugas M, Cocconcelli PS, Richard Forget F, Klein G, Licht TR, Nguyen-The C, Querol A, Richardson M, et al. Qualified presumption of safety (QPS): a generic risk assessment approach for biological agents notified to the European food safety authority (EFSA) Trends Food Sci Tech. 2010;21(9):425-35.

14. Pohl S, Harwood CR. Heterologous protein secretion by Bacillus species: from the cradle to the grave. Adv Appl Microbiol. 2010;73:1-25.

15. Zweers JC, Barak I, Becher D, Driessen AJM, Hecker M, Kontinen VP, Saller MJ, Vavrova L, Dijl JM. Towards the development of Bacillus subtilis as a cell factory for membrane proteins and protein complexes. Microb Cell Factories. 2008;7:10.

16. Xiao L, Zhang RH, Peng $Y$, Zhang $Y Z$. Highly efficient gene expression of a fibrinolytic enzyme (subtilisin DFE) in Bacillus subtilis mediated by the promoter of alpha-amylase gene from Bacillus amyloliquefaciens. Biotechnol Lett. 2004;26(17):1365-9.

17. Wu XC, Lee W, Tran L, Wong SL. Engineering a Bacillus subtilis expressionsecretion system with a strain deficient in six extracellular proteases. $J$ Bacteriol. 1991;173(16):4952-8.

18. Phuong ND, Jeong YS, Selvaraj T, Kim SK, Kim YH, Jung KH, Kim J, Yun HD, Wong SL, Lee JK, Kin H. Production of XynX, a large multimodular protein of Clostridium thermocellum, by protease-deficient Bacillus subtilis strains. Appl Biochem Biotechnol. 2012;168(2):375-82.
19. Ye RQ, Kim JH, Kim BG, Szarka S, Sihota E, Wong SL. High-level secretory production of intact, biologically active staphylokinase from Bacillus subtilis. Biotechnol Bioeng. 1999;62(1):87-96.

20. Durban MA, Silbersack J, Schweder T, Schauer F, Bornscheuer UT. High leve expression of a recombinant phospholipase C from Bacillus cereus in Bacillus subtilis. Appl Microbiol Biotechnol. 2007;74(3):634-9.

21. Nguyen T, Quyen TD, Le HT. Cloning and enhancing production of a detergent- and organic-solvent-resistant nattokinase from Bacillus subtilis VTCCDVN-12-01 by using an eight-protease-gene-deficient Bacillus subtilis WB800 Microb Cell Factories. 2013;12:79.

22. Wu SM, Feng C, Zhong J, Huan LD. Enhanced production of recombinant nattokinase in Bacillus subtilis by promoter optimization. World J Microb Biotechnol. 2010;27(1):99-106.

23. Zhang AL, Liu H, Yang MM, Gong YS, Chen H. Assay and characterization of a strong promoter element from B. subtilis. Biochem Biophys Res Commun 2007;354(1):90-5.

24. Li W, Li HX, Ji SY, Li S, Gong YS, Yang MM, Chen YL. Characterization of two temperature-inducible promoters newly isolated from $B$. subtilis. Biochem Biophys Res Commun. 2007:358(4):1148-53.

25. Yang M, Zhang W, Ji S, Cao P, Chen Y, Zhao X. Generation of an artificial double promoter for protein expression in Bacillus subtilis through a promoter trap system. PLoS One. 2013;8(2):e56321.

26. Han L, Suo F, Jiang C, Gua J, Li N, Zhang N, Cui W, Zhou Z. Fabrication and characterization of a robust and strong bacterial promoter from a semirationally engineered promoter library in Bacillus subtilis. Process Biochem. 2017;61:56-62.

27. Cheng J, Guan C, Cui W, Zhou L, Liu Z, Li W, Zhou Z. Enhancement of a high efficient autoinducible expression system in Bacillus subtilis by promoter engineering. Protein Expres Purif. 2016;127:81-7.

28. Guan C, Cui W, Cheng J, Zhou L, Liu Z, Zhou Z. Development of an efficient autoinducible expression system by promoter engineering in Bacillus subtilis. Microb Cell Factories. 2016;15:66.

29. Widner B, Thomas M, Sternberg D, Lammon D, Behr R, Sloma A. Development of marker-free strains of Bacillus subtilis capable of secreting high levels of industrial enzymes. J Ind Microbiol Biot. 2000; 25(4):204-12.

30. Kang HK, Jang JH, Shim JH, Park JT, Kim YW, Park KH. Efficient constitutive expression of thermostable 4-a-glucanotransferase in Bacillus subtilis using dual promoters. World J Microbiol Biotechnol. 2010;26:1915-8.

31. Guan C, Cui W, Cheng J, Liu R, Liu Z, Zhou L, Zhou Z. Construction of a highly active secretory expression system via an engineered dual promoter and a highly efficient signal peptide in Bacillus subtilis. New Biotechnol. 2016:33:372-9.

32. Zhang K, Su L, Duan X, Liu L, Wu J. Highlevel extracellular protein production in Bacillus subtilis using an optimized dualpromoter expression system. Microb Cell Factories. 2017;16:32.

33. Okegawa Y, Motohashi K. Expression of spinach ferredoxin-thioredoxin reductase using tandem $\mathrm{T} 7$ promoters and application of the purified protein for in vitro light-dependent thioredoxin-reduction system. Protein Expres Purif. 2016;121:46-51.

34. Blazeck J, Alper HS. Promoter engineering: recent advances in controlling transcription at the most fundamental level. Biotechnol J. 2013:8:46-58.

35. Yue X, Cui X, Zhang Z, Hu W, Li Z, Zhang Y, Li Y. Effects of transcriptional mode on promoter substitution and tandem engineering for the production of epothilones in Myxococcus xanthus. Appl Microbiol Biotechnol. 2018;102:5599-610.

36. Li M, Wang J, Geng Y, Li Y, Wang Q, Liang Q, Qi Q. A strategy of gene overexpression based on tandem repetitive promoters in Escherichia coli. Microb Cell Factories. 2012;11:19.

37. Phanaksri T, Luxananil P, Panyim S, Tirasophon W. Synergism of regulatory elements in sigma(B)- and sigma(a)-dependent promoters enhances recombinant protein expression in Bacillus subtilis. J Biosci Bioeng. 2015;120(4):470-5

38. Wei WZ, Xiang $H$, Tan HR. Two tandem promoters to increase gene expression in Lactococcus lactis. Biotechnol Lett. 2002;24(20):1669-72.

39. Suwanmanon K, Hsieh PC. Isolating Bacillus subtilis and optimizing its fermentative medium for GABA and nattokinase production. Cyta-J Food. 2014:12(3):282-90

40. Wei X, Zhou Y, Chen J, Cai D, Wang D, Qi G, Chen S. Efficient expression of nattokinase in Bacillus licheniformis: host strain construction and signal peptide optimization. J Ind Microbiol Biotechnol. 2015;42(2):287-95. 
41. Miyazaki K, Takenouchi M. Creating random mutagenesis libraries using megaprimer PCR of whole plasmid. BioTechniques. 2002;33(5):1033-4 1036-1038.

42. Miyazaki K. MEGAWHOP cloning: a method of creating random mutagenesis libraries via megaprimer PCR of whole plasmids. Methods Enzymol. 2011;498:399-406.

43. Anagnostopoulos C, Spizizen J. Requirements for transformation in Bacillus Subtilis. J Bacteriol. 1961;81(5):741-6.

44. Bott KF, Wilson GA. Development of competence in the Bacillus subtilis transformation system. J Bacteriol. 1967;94(3):562-70.

45. Weng M, Zheng Z, Bao W, Cai Y, Yin Y, Zou G. Enhancement of oxidative stability of the subtilisin nattokinase by site-directed mutagenesis expressed in Escherichia coli. Biochim Biophys Acta. 2009;1794(11):1566-72.

Ready to submit your research? Choose BMC and benefit from:

- fast, convenient online submission

- thorough peer review by experienced researchers in your field

- rapid publication on acceptance

- support for research data, including large and complex data types

- gold Open Access which fosters wider collaboration and increased citations

- maximum visibility for your research: over $100 \mathrm{M}$ website views per year

At $\mathrm{BMC}$, research is always in progress.

Learn more biomedcentral.com/submissions 